Article

\title{
Emplacement and Segment Geometry of Large, High-Viscosity Magmatic Sheets
}

\author{
Tobias Schmiedel ${ }^{1, *}\left(\mathbb{D}\right.$, Steffi Burchardt ${ }^{1,2, *}$, Tobias Mattsson ${ }^{3,4}{ }^{(0)}$, Frank Guldstrand ${ }^{5}$, Olivier Galland ${ }^{5}$, \\ Joaquín Octavio Palma ${ }^{6,7}$ and Henrik Skogby ${ }^{8}$ (i)
}

1 Department of Earth Sciences, Uppsala University, 75236 Uppsala, Sweden

2 Center for Natural Hazard and Disaster Science, Uppsala University, 75236 Uppsala, Sweden

3 School of Earth and Environmental Sciences, University of St. Andrews, St. Andrews KY16 9TS, UK; tobias.mattsson@geo.su.se

4 Department of Geological Sciences, Stockholm University, 10961 Stockholm, Sweden

5 The NJORD Centre, Department of Geosciences, University of Oslo, 0316 Oslo, Norway; olivier.galland@geo.uio.no (O.G.)

6 Subsecretariat of Mining of the Province of Buenos Aires, La Plata 1900, Argentina; joaquinoctaviopalma@gmail.com

7 Faculty of Natural Sciences and Museum, National University of La Plata, La Plata 1900, Argentina

8 Department of Geosciences, Swedish Museum of Natural History, 10405 Stockholm, Sweden; henrik.skogby@nrm.se

* Correspondence: tobias.schmiedel@geo.uu.se (T.S.); Steffi.burchardt@geo.uu.se (S.B.)

Citation: Schmiedel, T.; Burchardt, S. Mattsson, T.; Guldstrand, F.; Galland,

O.; Palma, J.O.; Skogby, H.

Emplacement and Segment Geometry of Large, High-Viscosity Magmatic Sheets. Minerals 2021, 11, 1113. https://doi.org/10.3390/min11101113

Academic Editors: Craig Magee, Qiliang Sun and William McCarthy

Received: 27 May 2021

Accepted: 2 October 2021

Published: 11 October 2021

Publisher's Note: MDPI stays neutral with regard to jurisdictional claims in published maps and institutional affiliations.

Copyright: (C) 2021 by the authors Licensee MDPI, Basel, Switzerland. This article is an open access article distributed under the terms and conditions of the Creative Commons Attribution (CC BY) license (https:// creativecommons.org/licenses/by/ $4.0 /)$.

\begin{abstract}
Understanding magma transport in sheet intrusions is crucial to interpreting volcanic unrest. Studies of dyke emplacement and geometry focus predominantly on low-viscosity, mafic dykes. Here, we present an in-depth study of two high-viscosity dykes $\left(10^{6} \mathrm{~Pa} \cdot \mathrm{s}\right)$ in the Chachahuén volcano, Argentina, the Great Dyke and the Sosa Dyke. To quantify dyke geometries, magma flow indicators, and magma viscosity, we combine photogrammetry, microstructural analysis, igneous petrology, Fourier-Transform-Infrared-Spectroscopy, and Anisotropy of Magnetic Susceptibility (AMS). Our results show that the dykes consist of 3 to 8 mappable segments up to $2 \mathrm{~km}$ long. Segments often end in a bifurcation, and segment tips are predominantly oval, but elliptical tips occur in the outermost segments of the Great Dyke. Furthermore, variations in host rocks have no observable impact on dyke geometry. AMS fabrics and other flow indicators in the Sosa Dyke show lateral magma flow in contrast to the vertical flow suggested by the segment geometries. A comparison with segment geometries of low-viscosity dykes shows that our high-viscosity dykes follow the same geometrical trend. In fact, the data compilation supports that dyke segment and tip geometries reflect different stages in dyke emplacement, questioning the current usage for final sheet geometries as proxies for emplacement mechanism.
\end{abstract}

Keywords: magma transport; high-viscosity dykes; shallow crust; igneous; sills; Chachahuen volcano; anisotropy of magnetic susceptibility (AMS); magma flow indicator

\section{Introduction}

Dykes and sills, (sub-)vertical and (sub-)horizontal sheet intrusions, respectively, are unarguably some of the most fundamental magma transport pathways in the Earth's crust [1-3] and references therein. They can effectively supply magma to and from existing magma reservoirs and towards volcanic eruptions at the Earth's surface (e.g., [4-6]). Sheet intrusions are most dominantly recognized as transport pathways and feeders of mafic, low-viscosity magmas [2,7,8], whereas the feeders of felsic, high-viscosity magma eruptions are commonly considered to be sub-circular conduits [9-11]. However, field observations of exposed volcanic plumbing systems $[12,13]$ and geophysical observations at active volcanoes $[6,14]$ show that high-viscosity, felsic intrusions can also exhibit sheet geometries 
and can be the main feeders of explosive eruptions, as well as cryptodomes and lava domes $[15,16]$.

The low values of thickness-to-length aspect ratios of sheet intrusions have been interpreted as indicators of emplacement as Mode I tensile fractures [2,17-20]. In agreement with this model, field observations of sharp intrusion tip geometries have been mostly described for low-viscosity magma [18,21-23]. However, observed tips of high-viscosity magma intrusions exhibit blunt shapes [21,24-26], suggesting another emplacement mechanism than Mode I tensile fracturing [21,24,27]. Recent studies of low-viscosity magma sheet intrusions observed blunt tip shapes, suggesting the need to consider alternative emplacement mechanisms for mafic sheet intrusions as well [21,28,29]. These contrasting tip shapes suggest that the emplacement of low-viscosity and high-viscosity sheet intrusions might be different. This implies that an overall sheet shape may not be a relevant proxy for an intrusion emplacement mechanism [21,30-32]. However, due to the scarcity of silicic and crystal-rich sheet intrusions, their emplacement is poorly understood. Better constraining the emplacement mechanisms of felsic sheet intrusions thus requires additional data on (1) magma flow proxies within the intrusion, such as the orientation of crystals, e.g., ferro magnetic grains, within the intrusions [33-35], and (2) outside the intrusion, such as deformation structures in the host rock $[26,27,36,37]$.

There is growing evidence that dykes can be the feeders of felsic (dacitic to rhyolitic) explosive eruptions, such as the 2008 Chaitén eruption [6,38] and the 2011-2012 Cordón Caulle eruption $[14,39]$. Geophysical and geodetic data measured at these volcanoes are interpreted using models based on tensile elastic assumptions to constrain magma source, volume, and transport mechanisms. However, the results of these models are often in mismatch when compared with actual erupted material or our current understanding of magmatic systems $[14,38,40]$. This highlights the still existing knowledge gap between field observations, the actual process of magma transport in sheet intrusions and the associated geophysical and geodetic unrest signals during their emplacement (cf. [41,42]). Understanding high-viscosity magma transport along sheet intrusions is thus essential for revealing the dynamics of volcanoes erupting felsic magma and for better constraining precursors of explosive eruptions.

To bridge the gap between surface data, i.e., field observations of exposed magmatic sheets, indirect geophysical measurements, and the actual subsurface processes of high-viscosity magma transport, we studied the three-dimensional geometry of two exceptionally well-exposed felsic, crystal-rich dykes in the Miocene Chachahuén volcano in Argentina and investigated their internal features as proxies of magma transport. We combine 3D-photogrammetry, geochemistry, AMS (anisotropy of magnetic susceptibility), and petrology to present quantitative data on the geometry of the dykes, as well as their magma viscosity. Our results enable us to quantitatively compare the geometry and emplacement indicators of our high-viscosity dykes with their low-viscosity equivalents.

\section{Geological Setting}

The two dykes studied in this contribution belong to the Miocene Chachahuén volcano, an extinct caldera volcano located in the northern part of the Neuquén basin, western Argentina (Figure 1). Chachahuén belongs to the Payenia back-arc volcanic province of the Andes [43,44].

The earliest exposed volcanic rocks recording the multi-stage history of Chachahuén [45-47] belong to the Early Miocene Matancilla basalts that were erupted in fissure eruptions over large areas. The main phase of activity of Chachahuén is characterised by basaltic to rhyolitic effusive to explosive activity building a large volcanic edifice during the Late Miocene [48]. The bulk of the edifice is made up of voluminous hornblende-bearing andesite block-and-ash flows that overlie the basalts and rhyolites. The block-and-ash flows most likely resulted from the collapse of domes and cryptodomes. Some of these (crypto)domes are preserved, the largest of which is the Cerro Bayo cryptodome with an 
age of $6.7 \pm 0.3 \mathrm{Ma}$ [48]. The Sosa Dyke described in this study is located to the west of Cerro Bayo and follows the trace of a pre-existing fault [49] (Figure 1).

Activity commenced with some block-and-ash flows, but became more effusive, creating a pile of hornblende- and plagioclase-porphyritic lava flows. At some point during this phase, the Chachahuén volcano experienced caldera collapse, forming a large depression $[45,46]$. The steep western fault scarp of the caldera (Figure 1) exposes a section through the stratigraphy including the block-and-ash-flows, a prominent white ignimbrite and the andesite lavas.

The caldera interior was likely modified by subsequent eruptions and erosion, judging from the remnants of a swarm of radial dykes that cut through all parts of the stratigraphy and often stand out as walls (Figure 1B). The Great Dyke [45] described in this study is part of this radial dyke swarm and crosscuts the caldera wall (Figure 1).

Following a hiatus, volcanic activity shifted eastward to what is Cerro Chachahuén today. From there, thin basaltic lava flows were erupted covering much of the volcano [45] before central volcanic activity ceased. During the Quaternary, volcanism has been restricted to monogenetic eruptions dispersed over large areas beyond the Chachahuén volcanic centre.

At present the interior and flanks of the Chachahuén volcano are deeply eroded, in places down to the sedimentary basement. The caldera interior hosts strongly altered remnants of the Matancilla basalts overlying the Mesozoic sedimentary rocks [50], as well as an altered sequence of rhyolites and basalts, overlain by andesitic block-and-ash-flows, all intruded by the radial dykes.

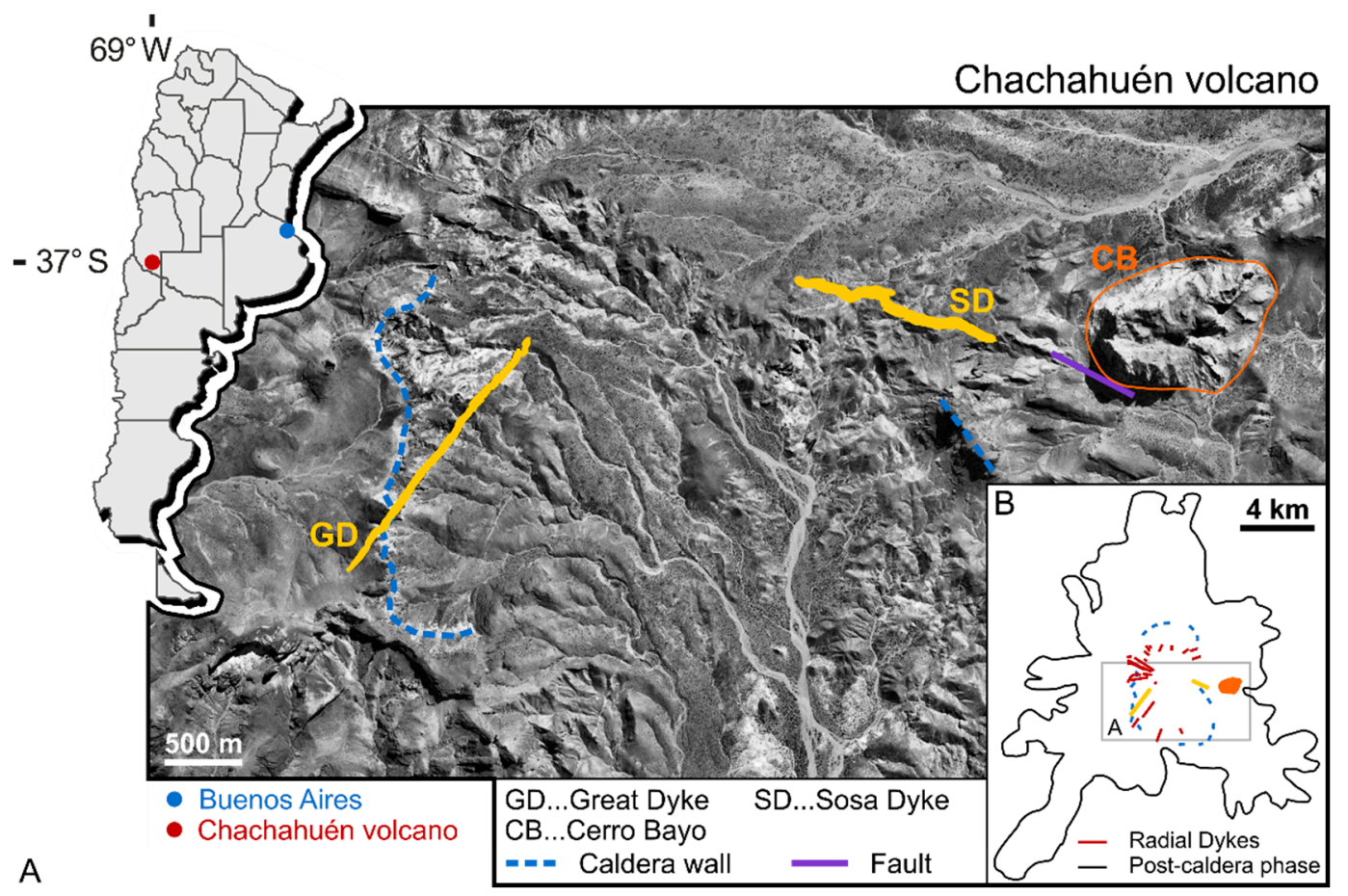

Figure 1. Overview of Chachahuén volcano (A) Map of Argentina for location (modified after Drawnhy97-Freepik.com). Dykes in this study (yellow): Great Dyke (GD) and Sosa Dyke (SD); Cerro Bayo Cryptodome (CB, orange outline) from [49] on satellite photo: (Source: Google Earth). (B) Schematic drawing of Chachahuén volcano outline of andesitic block-andash-flows and andesitic lavas in the post-caldera phase. Similar to (A) dykes in this study (yellow): Great Dyke and Sosa Dyke; Cerro Bayo Cryptodome (orange shape); Caldera outline (blue dashed line). 


\section{Methods}

\subsection{Field Work and Photogrammetry}

The field work for this study took place in November 2018 at the Chachahuén volcano in Argentina. To aid the field observations of the Sosa Dyke and the Great Dyke (Figure 1) we used a DJI Phantom 4 Pro UAS (Unmanned Aerial System) to take overlapping photos (Resolution: $5472 \times 3648$ pixels) for a subsequent photogrammetric analysis. The acquired drone photos were the input for Structure from Motion (SfM) photogrammetry analysis using Metashape (Agisoft Version 1.7.0). We apply the default workflow in Agisoft Metashape to generate two virtual outcrop models of the Sosa Dyke and Great Dyke, respectively (available via: https:/ /v3geo.com/, accessed on 4 October 2021). In addition, we generated the orthophotos of the Sosa Dyke (285 photos, orthophoto resolution: $5 \mathrm{~cm}$ ) and Great Dyke (498 photos, orthophoto resolution: $5 \mathrm{~cm}$ ) from the 3D data. Subsequently, we used the software MOVE 2019 (by Petroleum Experts) to map the dyke geometries and segments. For each dyke we created virtual cross-sections orthogonal to the strike of the dyke (cross section spacing: $5 \mathrm{~m}$ ) over its full length. Each exported cross-section contained the coordinates of the intersection points of the mapped dyke outline with the cross-section-plane. This data was imported into MATLAB 2019b (MathWorks ${ }^{\circledR}$ ) and used to calculate the thickness of the dykes for each virtual cross-section. The MATLAB code including the two example datasets for the Sosa and Great Dyke are available via github [51] (https:// doi.org/10.5281/zenodo.4784164). This allowed us to quantify the distribution of the thicknesses for each segment of the Sosa Dyke and the Great Dyke. In the case of a bifurcation in the dyke, we computed multiple thicknesses and considered the thickest measurement as part of the data. Note that parts of segments that overlap other segments of the dyke were not considered in the calculation of average thickness and standard deviation. Further, to quantify the geometry of each segment we measured the radius $r_{\text {tip }}$ of the segment tips, the width $w$ (long axis) and the thickness $t$, (short axis) of a segment, following a method developed by Pollard et al. [25] and recently used by Stephens et al. [28].

\subsection{Rock Samples and AMS Analysis}

We collected oriented rock samples along two traverses across the Sosa Dyke and rock samples from each margin and centre of the Great Dyke. The two traverses across the Sosa Dyke are located (Figure 2): in the middle of a segment traverse T1 and close to the tip of a segment traverse T2, both with a sample spacing of $5 \mathrm{~m}$. The collected rock samples were drilled and 9 to 14 drill cores ( $24 \mathrm{~mm}$ diameter, $21 \mathrm{~mm}$ length) per sample, suitable for anisotropy of magnetic susceptibility (AMS) analysis, were extracted. Only sample T1-09 contained too many fractures such that no cores could be recovered. Low-field AMS was employed to investigate the flow direction in two of the dyke segments of the Sosa Dyke. The measurements of the in-phase anisotropy of the magnetic susceptibility (ipAMS) were performed at the Laboratory for Experimental Paleo-magnetism at the Department of Earth Sciences, Uppsala University in Uppsala, Sweden. We performed the measurements with an Agico Kappabridge MK1-FA (Agico, Brno, Czech Republic) in semi-automatic spin-mode (magnetic field: $200 \mathrm{~A} / \mathrm{m}$, frequency $976 \mathrm{~Hz}$ ). Symmetric second rank magnetic susceptibility tensors were determined from the susceptibility measurements using the least square inversion method of Jelínek [52]. The eigenvalues and eigenvectors of the magnetic susceptibility tensor define the value and orientation of the three orthogonal, principal axes of susceptibility, $\mathrm{k}_{1} \geq \mathrm{k}_{2} \geq \mathrm{k}_{3}$, represented by a triaxial ellipsoid [53]. The following parameters are used to describe the magnetic fabric responsible for the AMS signal [54] in the Sosa Dyke: (1) $K_{\text {mean }}\left(K_{\text {mean }}=\left(k_{1}+k_{2}+k_{3}\right) / 3\right)$, (2) $P_{j}$ the corrected degree of anisotropy:

$$
P_{j}=\exp \sqrt{2\left(\left(\eta_{1}-\eta_{m}\right)^{2}+\left(\eta_{2}-\eta_{m}\right)^{2}+\left(\eta_{3}-\eta_{m}\right)^{2}\right)}
$$


with $\eta_{x}=\ln \left(\mathrm{k}_{\mathrm{x}}\right), x=1,2,3$ and $\eta_{m}=\frac{\eta_{1}+\eta_{2}+\eta_{3}}{3}$, where a value of 1 represents an isotropic fabric and values $>1$ increasing degrees of fabric anisotropy, (3) $\mathrm{T}$ the shape factor $(\mathrm{T}=1$, rotational oblate; $\mathrm{T}=-1$, rotational prolate, $\mathrm{T}=0$, spherical) is defined as:

$$
T=\frac{2 \eta_{2}-\eta_{1}-\eta_{3}}{\eta_{1}-\eta_{3}}
$$

(4) $\mathrm{L}$ the magnetic lineation is defined as: $\mathrm{L}=\left(\mathrm{k}_{1} / \mathrm{k}_{2}\right)$, and (5) $\mathrm{F}$ the magnetic foliation $\left(\mathrm{F}=\left(\mathrm{k}_{2} / \mathrm{k}_{3}\right)\right.$ were obtained with the software Anisoft5 (Agico, Version 5.1.08) [55].

The out-of-phase AMS (opAMS) was measured on half of the cores of traverse T1 and all of the cores of traverse T2 using a KLY-5a Kappabridge at the University of St. Andrews $\mathrm{M}^{3}$ Ore lab in 3D automatic spin mode with a magnetic field of $400 \mathrm{~A} / \mathrm{m}$ and at a frequency of $1440 \mathrm{~Hz}$. Out-of-phase AMS measured the viscous magnetic response as the applied magnetic field is switched off $[56,57]$. Out of phase AMS may therefore help single out the signal of magnetically viscous grains in ipAMS and identify the fabric of small pseudo single-domain magnetite. In some instances, opAMS can work as a substitute to anisotropy of anhysteretic magnetic remanence [57].

To characterise magnetic carriers, we performed temperature versus magnetic susceptibility measurements, demagnetisation of the natural remnant magnetization and anhysteretic remanence magnetization on selected samples. The temperature vs. susceptibility measurements were performed with the CS4 attachment to the Agico Kappabridge MK1-FA by heating powdered samples to $700{ }^{\circ} \mathrm{C}$ in an argon atmosphere and subsequently cooled back to room temperature. The samples were demagnetized and magnetized with an Agico LDA 5 AF demagnetizer FA and Agico PAM1 FA, respectively at the $\mathrm{M}^{3}$ Ore lab at the University of St. Andrews. The sample magnetization was measured with a Agico JR6-a spinner magnetometer with an automatic sample holder. The variation in susceptibility at different temperatures and demagnetization/magnetization behaviour of the samples can help us to distinguish the ferromagnetic mineral phases responsible for the AMS signal in the dyke samples. In addition to the measurement of the AMS, we performed anisotropy of anhysteretic remanence magnetization (AARM) and anisotropy of isothermal remanence magnetization (AIRM) on selected cores to further pinpoint the carriers of the AMS fabrics. The samples were demagnetized using $150 \mathrm{mT}$ alternating field (AF) with a 2-axis tumbling specimen holder, prior to imparting an ARM on six sample orientations according to orientation scheme of Hext [58] and Jelínek [59]. The ARM was imparted using a bias direct current field of $500 \mu \mathrm{T}$ in a peak AF of $130 \mathrm{mT}$. For AIRM, the samples were imparted with an IRM in six orientations using a single, one second pulse direct current field of $20 \mathrm{mT}$ for samples from traverse $\mathrm{T} 1$ and $15 \mathrm{mT}$ on samples from traverse T2. The different IRM fields for the two traverses was based on the sample' NRM demagnetization and ARM magnetization (Figure A4). The samples were demagnetized in a field of $150 \mathrm{mT}$ using a tumbling specimen holder before imparting the IRM on each position. The results of the magnetic characterisation, AARM and AIRM measurements are presented in detail in Appendix B.

\subsection{Geochemistry and Petrographic Analysis}

In addition to the dyke's internal structure and propagation direction, the rheology of the transported magma is a crucial parameter for the dyke emplacement and geometry. The main parameters to describe the rheology of a magma is the chemical composition of the melt, and the size and content of the vesicles and particles, dispersed and transported in it.

From the rock samples we prepared 17 powder samples (15 g/sample) for whole rock major and trace element analysis (Appendix A.1). The major element analysis was performed via lithium borate fused bead ICP-AES (Inductively Coupled Plasma-Atomic Emission Spectroscopy) with major element oxide detection limits of $0.01 \mathrm{wt} \%\left(\mathrm{Cr}_{2} \mathrm{O}_{3}\right.$ : $0.001 \mathrm{wt} \%$; ALS Geochemistry: Me-ICP06, Vancouver, Canada) and LOI (Loss on Ignition) by furnace or thermogravimetric analysis (ALS Geochemistry: OA-GRA05/ME-GRA05). 
The trace element geochemistry was analysed via fused bead lithium borate ICP-MS (Inductively Coupled Plasma-Mass Spectrometry, ALS Geochemistry: MeMS81 ${ }^{\mathrm{TM}}$ ) with trace element oxide detection limits varying from $0.01 \mathrm{ppm}$ (caesium) to $5 \mathrm{ppm}$ (vanadium). In both major and trace element analysis the sample-lithium borate fused beads underwent acid digestion before being analysed in the ICP-AES/ICP-MS. The full geochemical dataset can be found in Appendix A.

We followed the recommendation of Jackson et al. [60] to not use the LOI values derived from whole rock geochemistry as proxy for the $\mathrm{H}_{2} \mathrm{O}$ content of the rocks, due to the potential larger error. Instead, we used the water content measured via FTIR spectroscopy of the magmatic glass [61,62]. The ERZLABOR in Freiberg/Germany prepared four doublesided polished thick sections of glass rich samples for FTIR (Fourier Transform Infrared) spectroscopy. Three of the thick sections from samples of the Sosa Dyke margin, to test the reproducibility of the values and one sample from the Great Dyke margin. The aim of the FTIR analysis was to precisely determine the $\mathrm{H}_{2} \mathrm{O}$ content in the glass as a proxy for the $\mathrm{H}_{2} \mathrm{O}$ content in the melt during emplacement. The FTIR analysis was performed at the Swedish Museum of Natural History in Stockholm/Sweden using a Bruker Vertex spectrometer equipped with a Globar source and a Potassium bromide (KBr) infrared beamsplitter. A Mercury Cadmium Telluride detector (MCT) and a Hyperion 2000 microscope were used to acquire spectra in the wavenumber range $4000-600 \mathrm{~cm}^{-1}$ with a resolution of $4 \mathrm{~cm}^{-1}$. On each thick section sample ten glass-matrix locations were measured to ensure reproducibility of the measurements within the sample (Figure A1). For the $\mathrm{H}_{2} \mathrm{O}$-content calculation we compared two different models: (1) single extinction coefficient $\varepsilon$ model, using the averaged $\varepsilon_{\mathrm{H} 2 \mathrm{O}}$ at $3550 \mathrm{~m}^{-1}$ of andesite and rhyolite [61], and (2) the endmember extinction coefficient model with two distinct $\varepsilon_{\mathrm{H} 2 \mathrm{O}}$ and $\varepsilon_{\mathrm{OH}}$ at $3550 \mathrm{~m}^{-1}$ for molecular water and hydroxyl groups, respectively $[62,63]$.

To investigate the size and composition of the vesicles and particles, the bubbles and phenocrysts, respectively, we used polished thin sections of the rock samples prepared at the ERZLABOR in Freiberg/Germany. The petrographic analysis comprises the main mineral determination as well as point counting (c. 300 counts per thin sections; Table A4). The point counting values were used as a proxy for the crystal content and differentiated between matrix and phenocrysts.

Finally, the results from: (1) the FTIR spectroscopy derived values of $\mathrm{H}_{2} \mathrm{O}$ content of the glass, together with (2) the major element whole geochemistry, and (3) the crystal content calculated from the thin sections, were used as input parameters for MAGMA (KWare Geological Software: https:/ /www.lanl.gov /orgs/ees / geodynamics/Wohletz/ KWare/Index.htm, accessed on 4 October 2021) developed by Ken Wohletz (Los Alamos National Laboratory). The magma viscosity calculation is based on the viscosity model after Bottinga and Weill [64]. The record of input and output of the MAGMA tool is available in Supplementary Material "MAGMArecord.zip".

\section{Results}

\subsection{Sosa Dyke}

The Sosa Dyke is located in the Northern part of the Chachahuén volcano, with a total length of c. $1300 \mathrm{~m}$ (measurement along strike; Figure 1). Its exposure suggests that the dyke is a vertical sheet $\left(\sim 88^{\circ}\right)$ with an overall strike of $277^{\circ}$. Due to outcrop quality, this study will focus on the eastern $950 \mathrm{~m}$ of the Sosa Dyke only, where we mapped three different dyke segments (I-III, Figure 2). The host rock into which the Sosa Dyke intrudes is a succession of (sub-)horizontally bedded block-and-ash-flows and dacitic to rhyolitic ignimbrites. The Eastern exposed tip of the Sosa Dyke is only c. $600 \mathrm{~m}$ in strike direction away from a massive igneous intrusion, the Cerro Bayo cryptodome (Figures 1 and 3A) [49].

The eastern most segment, Segment $I$, is at $560 \mathrm{~m}$ the longest mapped segment of the Sosa Dyke. It has an average thickness of around $42 \mathrm{~m}$ with a c. $50 \mathrm{~m}$ long area in the middle of the segment, which is significantly thicker (up to $65 \mathrm{~m}$ ) compared to the rest of the segment (30-50 m; Figure 2). At this thickened mid-point, the strike of the segment 
changes from $299^{\circ}$ to $274^{\circ}$. The East end of segment $I$ exhibits a narrowed, rounded tip, whereas the Western end of segment $I$ and the East end of segment $I I$, are hardly exposed (illustrated by the straight border between segments $I / I I$ in Figure 2).

Segment II is the shortest of the three mapped Sosa Dyke segments with a length of c. $210 \mathrm{~m}$ and a strike of $296^{\circ}$. This segment shows a gradual increase in thickness from its tips $(35 \mathrm{~m} / 25 \mathrm{~m})$ to the centre $(60 \mathrm{~m})$ with an average thickness of $48 \mathrm{~m}$. The Western end of segment II displays an overall blunt tip geometry (="squared ellipse shape/superellipse"; see $[65,66]$ for details), with two short $(<10 \mathrm{~m})$ pointy secondary tips at each corner (Figure 2).

Segment III strikes $277^{\circ}$ and has an average thickness of about $63 \mathrm{~m}$. Our observations indicate that segment III is not exposed in its entirety in the field. We confidently mapped a length of $203 \mathrm{~m}$ for segment III, although the orthophotos indicate the total length could be $10-32 \%$ longer. Due to insufficient outcrop conditions the termination and tip geometry of segment III in the West could not be observed. The East end of segment III has an offset of $57 \mathrm{~m}$ to the North of segment II with a segment overlap of $53 \mathrm{~m}$. Similar to segment II, the East end of segment III shows a blunt geometry. However, in contrast to segment II, we observe that only one prominent secondary tip (c. $40 \mathrm{~m}$ length, c. $23 \mathrm{~m}$ thick) has formed at the Northern corner ahead of segment III. In the field, host rock is exposed between segment II and segment III.

A common observation for the mapped segments of the Sosa Dyke seems to be the development of secondary tips towards the northeast on the East ends of the segments and towards the southwest on the West end of the segments (Figure 2). All segments, with the exception of segment II, display overall parallel margins that are smooth at the scale of the dyke. At outcrop scale, however, we observed a number of cuspate bulges that are part of the primary dyke geometry, i.e., not caused by erosion, as they exhibit chilled margins similar to the rest of the dyke. Furthermore, we observed large scale fractures in the Sosa Dyke, of which the majority showed a convex curvature towards the East (Figures 2 and $3 \mathrm{~A}, \mathrm{~B}$ ).

The chilled margin of the Sosa Dyke is dark and up to $15 \mathrm{~cm}$ thick, exhibiting a glassy matrix followed by a gradual transition $(10-20 \mathrm{~cm}$ thick) into a microlite-dominated matrix towards the centre of the dyke (Figure 3B). The part of this transition zone between glass- and microlite-dominated matrix closest to the dyke centre is often marked by a set of parallel fractures orthogonal to the dyke margin. These band-like sets of fractures were only a few $\mathrm{cm}$ in length, however neither field nor optical microscope revealed any apparent reason for why their opening stopped. The outermost margin of the Sosa Dyke contains a set of joints orthogonal to the dyke contact with a centimetre to decimetre spacing and up to $25 \mathrm{~cm}$ in length. This chilled margin texture is accompanied by a c. $25 \mathrm{~cm}$ wide zone of aligned hornblende and plagioclase crystals/crystal agglomerates parallel to the contact of the dyke and the host rock. Even so the alignment of crystals gets lost towards the centre of the dyke, the overall crystal content derived through point counting, stays similar with c. $35 \%$ at the margin and $37 \%$ in the centre of the Sosa Dyke (Figure 3D).

Along the contact of the Sosa Dyke with host rock, we observed centimetre to $0.8 \mathrm{~m}$ thick, vein-like structures that extended from the dyke margin into the host rock for several metres, striking at an angle of $15-30^{\circ}$ to the dyke. The veins are filled with light grey lithics with grain sizes ranging from clay to coarse sand and exhibiting fluidized sediment textures. The lithics seem to comprise both host rock material and occasionally dyke rock (Figures 2 and 3E,F). 


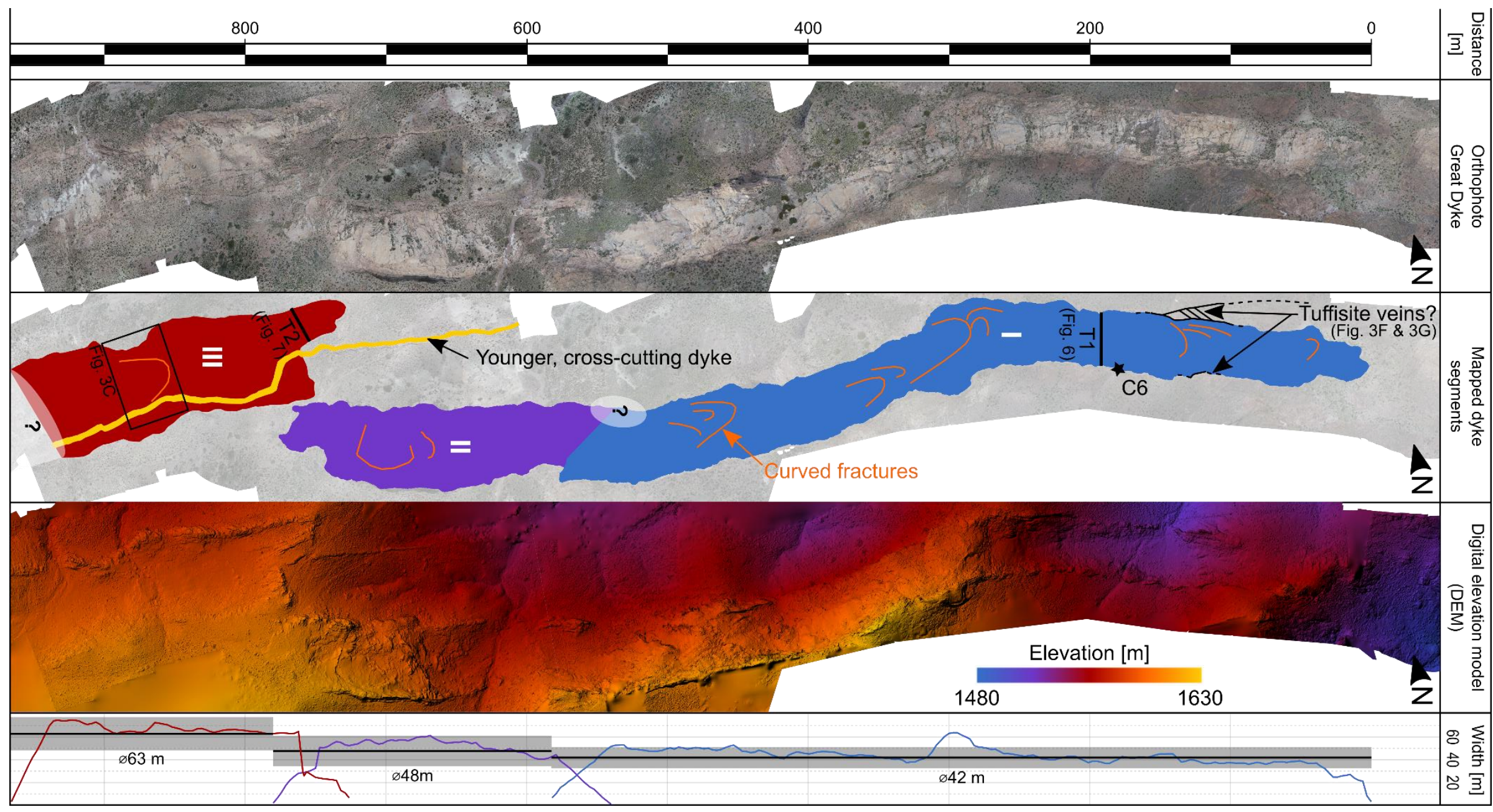

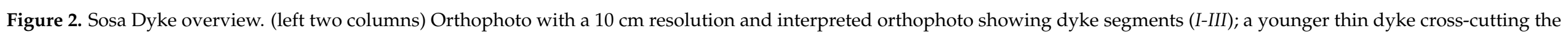

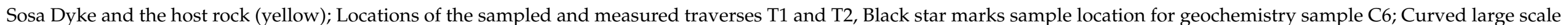

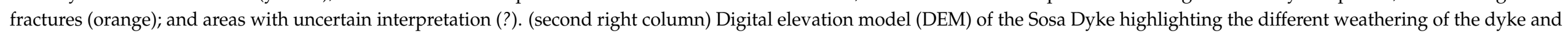

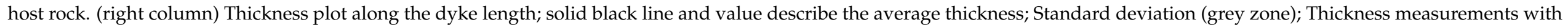
$5 \mathrm{~m}$ spacing (coloured lines). 

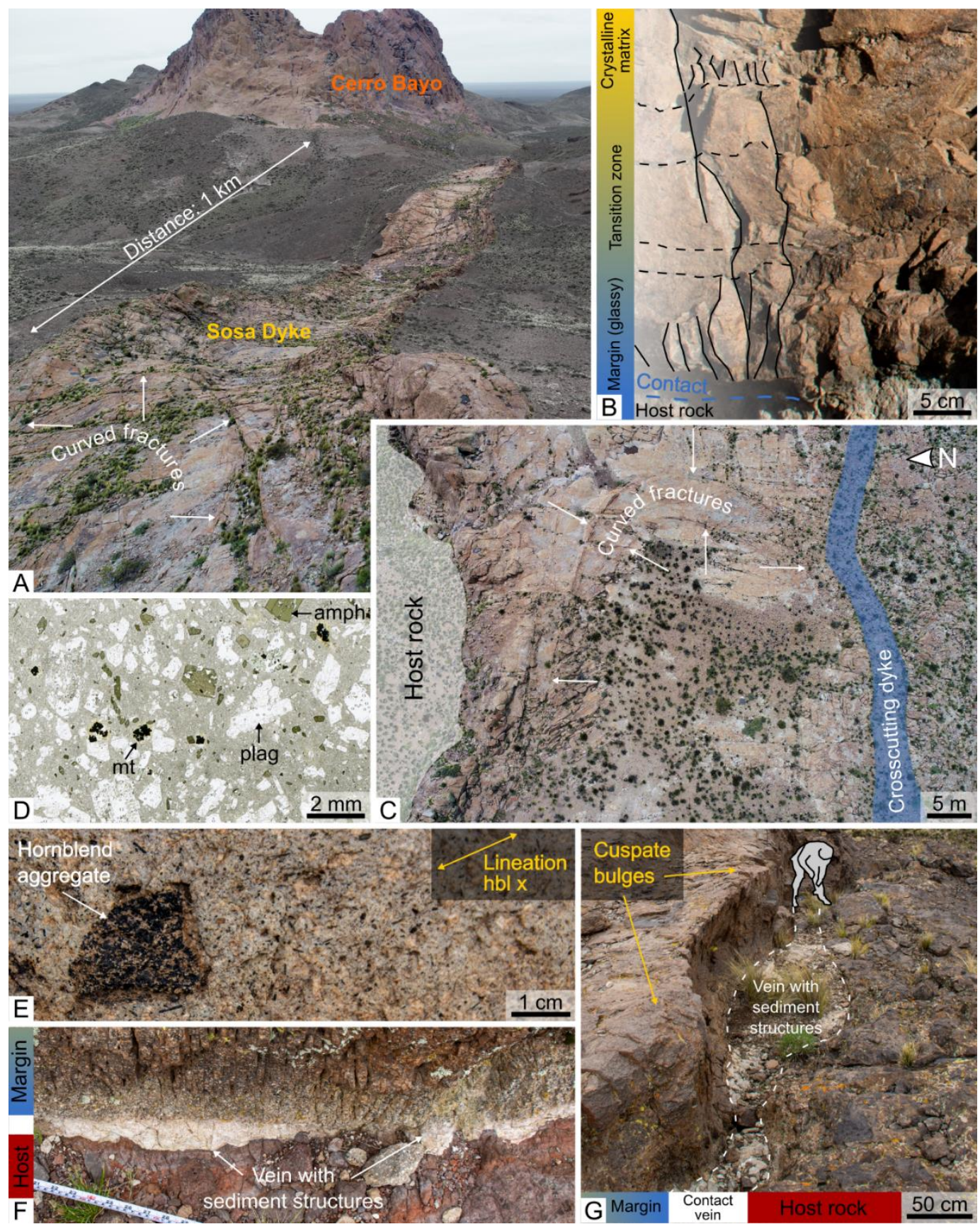

Figure 3. Sosa Dyke features. (A) View towards the East from the thickened mid-point in segment I, with Cerro Bayo crypto-dome in the background; curved fractures indicated by white arrows. (B) Close-up of margin with cooling joints at contact and second parallel fracture set at the inner end of the transition zone (solid black lines); contact parallel fractures (black dashed lines). (C) Top view on Sosa Dyke segment III (see Figure 4 for location), younger cross-cutting dyke and curved fractures toward the East indicated by white arrows. (D) Thin section, plain polarized light (PPL) from sample T1-05; white plagioclase phenocrysts, the fine-crystalline matrix consists of plagioclase, with minor amounts of mafic minerals; amph = amphibole group mineral, i.e., hornblende, $\mathrm{mt}=$ magnetite/Ti-magnetite; plag = plagioclase. (E) Photo shows large hornblende crystal and preferred orientation of hornblende crystals within the transition zone and the glassy margin of the Sosa Dyke. $(\mathrm{F}, \mathrm{G})$ Clast-filled veins along the contact between the Sosa Dyke the block and ash flow host rock; thickness less than a $\mathrm{cm}$ to around $80 \mathrm{~cm}$; Location in Figure 2-tuffisite veins. 


\subsection{Great Dyke}

The Great Dyke is located in the north-western part of the Chachahuén volcano, with a total length of c. $2000 \mathrm{~m}$ (Figures 1 and 4). Similar to the Sosa Dyke, the Great Dyke is a vertical sheet $\left(\sim 90^{\circ} \mathrm{dip}\right)$ and weathers out as a high wall from the surrounding host rocks (Figure 5). The Great Dyke strikes $218^{\circ}$, i.e., at an angle (c. $\left.25^{\circ}\right)$ to the caldera wall scarp (see Figure 1), cutting through the caldera infill consisting of block and ash flows and rhyolitic ignimbrite. Towards its southern end, the Great Dyke is exposed cutting through the entire caldera wall and pinching out in the lavas exposed in the highest elevations south of the caldera wall. The overall appearance of the dyke is a straight alignment of eight segments, with a decrease in thickness towards the outer segments (Figure 4).

Segment $I$ in the Northeast has a length of $78 \mathrm{~m}$ and a rather irregular shape with a strike of $197^{\circ}$. The segment reaches up to $27 \mathrm{~m}$ in its central part, but decreases in thickness towards the edges. The north-eastern tip of segment $I$ (the end of the dyke) is rounded, whereas the opposite tip is poorly defined as it is in contact with segment II (Figure 4).

Segment II is the shortest $(45 \mathrm{~m})$ of the eight mapped segments and the segment with the largest deviation in strike (strike: $240^{\circ}$ ) compared to the overall strike of the Great Dyke $\left(218^{\circ}\right)$. It has an average thickness of around $19 \mathrm{~m}$ with only minor changes in thickness towards the edges (Figure 4).

Segment III has a strike of $211^{\circ}$. Its north-eastern tip is bifurcated; one end connects to segment II the other end pinches out into a thin apophysis (length: $17 \mathrm{~m}$, width: c. $7 \mathrm{~m}$ ) with an offset towards the North. The length of segment III (excluding the apophysis) is $95 \mathrm{~m}$, its thickness averages at $22 \mathrm{~m}$ with several irregular indentations along the margins (Figure 4).

Segment $I V$ has a length of $145 \mathrm{~m}$ and a strike of $218^{\circ}$. The north-eastern end of segment $I V$ is blunt and offset towards the North in relation to segment III to which it is connected. Segment $I V$ has an average thickness of $23 \mathrm{~m}$ and straight parallel margins, resulting in a box-shaped/superellipse geometry. Only at the south-western end we observe a decrease in thickness down to $10 \mathrm{~m}$ at the connection to segment $V$ (Figure 4).

Segment $V$ strikes at $227^{\circ}$ with an average thickness of $25 \mathrm{~m}$ and a length of around $200 \mathrm{~m}$ (tip to tip; Figure 4). It is the only segment with a prominent bifurcation on both ends. Similar to the two previous segments, the north-eastern end of the segment is offset to the North in relation to is northern neighbour segment (i.e., segment $I V$ ). The north-eastern end of segment $V$ consists of: (1) a North-striking apophyse of $33 \mathrm{~m}$ in length, c. $7 \mathrm{~m}$ thick and with a pointy tip, and (2) the connection with segment $I V$. The bifurcation at the southwestern end of segment $V$ forms: (1) a connection with segment VI in the northern arm of the bifurcation, and (2) a South-striking apophysis of $22 \mathrm{~m}$ length and c. $7 \mathrm{~m}$ thickness and a pointy tip as the southern arm.

Segment $V I$ is the thickest segment (average thickness $34 \mathrm{~m}$ ) and located in the centre of the Great Dyke. It has a strike of $215^{\circ}$ and a length of $93 \mathrm{~m}$. In contrast to the previous three segments $(I I I-V)$, there is no bifurcation and offset to the North on the north-eastern end of the segment. In contrast, the south-western end of segment VI exhibits a potential secondary tip of a bifurcation towards the south, similar to segment III. The main (northern) part of this bifurcation is connected with the next segment VII.

Segment VII is by far the longest segment in the Great Dyke, with a length of $1110 \mathrm{~m}$ and a strike of $218^{\circ}$. The thickness of segment VII is fairly homogenous (average thickness $27 \mathrm{~m}$ ), due to the overall parallel dyke margins. However, our data shows a minor decrease in thickness to below $20 \mathrm{~m}$ over the last $80 \mathrm{~m}$ at each end. Segment VII displays the largest vertical exposure, both as a free-standing wall in the caldera and cutting through the cliff of the caldera wall. Within the cliff, no changes in thickness occur in different host rocks (Figure 5B). In contrast to most of the other segments of the Great Dyke, segment VII does not show any bifurcation at its ends. Both ends display a blunt geometry and an incision at the contact to the neighbouring segments. 


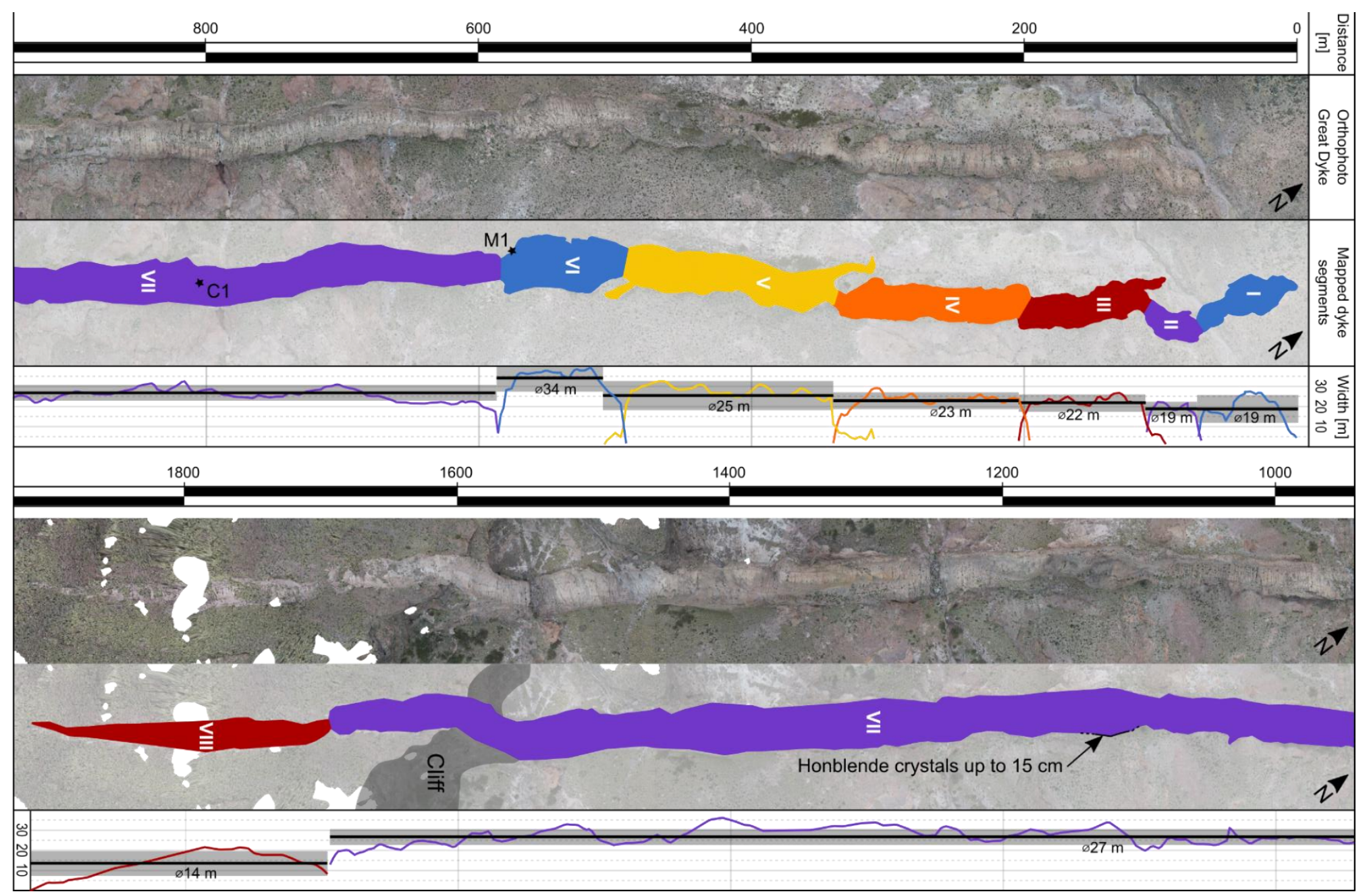

Figure 4. Great Dyke overview. (left column) Orthophoto with a $10 \mathrm{~cm}$ resolution. (middle column) Interpretation of the orthophoto showing dyke segments (I-VIII) Different colours are solely for visualisation purposes and do not reflect any specific properties of the segments; Vertical cliff c. $200 \mathrm{~m}$ (dark gray, see Figure 5A,B); Black stars mark the sample locations for whole rock geochemistry samples C1 and M1 (Figure A1). (right column) Thickness plot along the dyke length; solid black line and corresponding value describe the average thickness; Standard deviation (grey zone); Thickness measurements with $5 \mathrm{~m}$ spacing (coloured lines). 

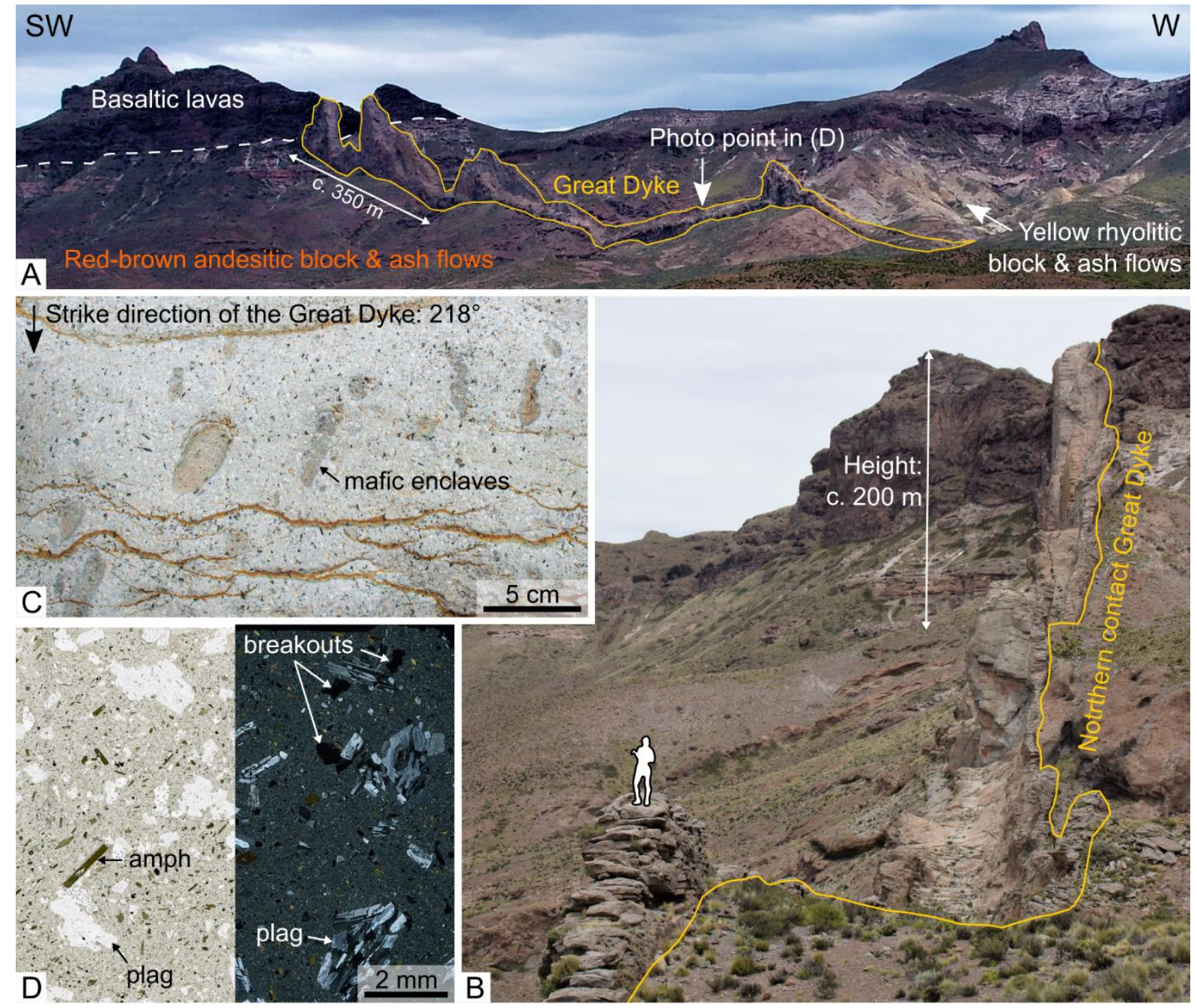

Figure 5. Great Dyke features: (A) Overview of the Great Dyke. (B) Outcrop photo Great Dyke along the dyke towards the southwest. (C) Detail photo in the centre of the Great Dyke, showing mafic enclaves with a long axis orientation parallel to the strike of the dyke. (D) Left: Thin section under plain polarized light (PPL), Right: crossed polarized light (XPL).

Segment VIII is exposed on a plateau, $200 \mathrm{~m}$ above the caldera depression. The segment is $220 \mathrm{~m}$ long with a strike of $217^{\circ}$. The thickness of segment VIII (14 m on average) reaches a maximum of $22 \mathrm{~m}$ in its centre. Towards the south-western end (end of the Great Dyke) the segment pinches out entirely. Hence, segment VIII is the segment with the largest asymmetry in geometry when comparing the tips of all dyke segments.

In the outcrop, the contact between the Great Dyke and its host rocks is sharp and characterised by a chilled margin in the dyke. In some outcrops, this chilled margin is weathered away, while the dyke interior is weathering out as a wall, with the north-western side often being up to $50 \mathrm{~m}$ higher in altitude than the south-eastern side of the dyke. Along the dyke walls, the chilled margin is up to $20 \mathrm{~cm}$ thick, dark and glass-rich with centimetre to decimetre spaced fractures. The chilled margin is dominated by elongated plagioclase phenocryst aggregates, parallel to the contact of the dyke. It is followed by a transition zone (c. $25-30 \mathrm{~cm}$ thick) with a gradually decreasing amount of glass in the matrix and an increasing number of microcrystals towards the centre of the Great Dyke. Notably, at segment ends, the thickness of the glassy chilled margin is much higher, in some places up to $<50 \mathrm{~cm}$. 
Throughout the Great Dyke we observe centimetre to decimetre in size, mafic enclaves in the dyke centre. Most of the enclaves are orientated with their longest axis parallel to the strike of the dyke (Figure $5 \mathrm{C}$ ). The crystal content is $30 \%$. In contrast to the crystals at the margin of the Great Dyke, plagioclase agglomerates and amphibole group minerals (i.e., hornblende) in the dyke centre show no preferred orientation (Figure 5D). In a narrow stretch of about 30-50 m along the southern margin of segment VII we observed hornblende megacrysts up to $15 \mathrm{~cm}$ in length (Figure 4).

\subsection{Anisotropy of Magnetic Susceptibility (AMS)}

The samples in traverse $\mathrm{T} 1$ in the Sosa Dyke have a mean susceptibility ranging from 17 to $26 \times 10^{-3}$ SI. The degree of anisotropy $P_{j}$ ranges from 1.02 to 1.04 and the shape of the AMS ellipsoid is moderately prolate to moderately oblate ( $\mathrm{T}=-0.62$ to 0.7$)$. The ipAMS foliation is moderately to steeply dipping and sub parallel to the strike of the dyke in six samples of the traverse T1 (T1-01, T1-02, T1-03, T1-05, T1-06 and T1-07) (Figure 6). The foliation in the remaining two samples are perpendicular to the strike of the dyke (T1-04 and $\mathrm{T} 1-08)$. The $\mathrm{k} 1$ orientation plots on or close to the dyke plane in samples T1-05, T1-07, T1-06, whereas it is obliquely oriented to the dyke plane in T1-01, T1-02 and T1-03, and perpendicular to the dyke plane in T1-08 and T1-04 (Figure 6). The magnetic foliation dip towards the NNE in T1-01, T1-02, T1-03 and is parallel to the dyke plane T1-05, T1-06 and T1-07. The opAMS is co-axial to the ipAMS in sample T1-05 (Figure A5). In T1-06, T1-07 and T1-08, the opAMS are non-coaxial to the ipAMS, which could indicate the presence of a magnetic subfabric carried by smaller magnetite crystals (Figure A5).

In the traverse $\mathrm{T} 2$ of the Sosa dyke the degree of anisotropy ranges from 1.01 to 1.04 and the shape of the AMS ellipsoid is moderately prolate to oblate ( $\mathrm{T}=-0.67$ to 0.83 ). The degree of anisotropy is lower at the margin and in the central part of the dyke compared to samples from between the margin and centre (Figure 7 ). The mean $\mathrm{k}_{1}$ orientation is trending parallel to the dyke plane in samples T2-01, T2-04, and T2-05, whereas the $\mathrm{k}_{1}$ orientation is slightly oblique to the dyke plane in T2-03, and T2-06. The magnetic foliation is dipping steeply towards the NW in T2-02, T2-03, and T2-04 and steeply to shallowly towards the SW in sample T2-05 and T2-06 (Figure 7). The opAMS shows higher degrees of anisotropy than the ipAMS in T2 samples. The opAMS is co-axial to the ipAMS in sample T2-02, T2-04, and T2-06 however, yield a higher spread of the data both in orientation and in fabric shape (Figure A6). In T2-01, and T2-05, the opAMS are non-coaxial to the ipAMS, which could indicate the presence of a magnetic subfabric carried by smaller magnetite crystals. (Figure A6). All magnetic data are given in Supplementary Material "Magnetic data.xlsx".

To identify carriers of the AMS fabric, we performed temperature vs. susceptibility experiments. Those temperature vs. susceptibility experiments together with $\mathrm{K}_{\mathrm{m}}$ values of $10^{-2}$ in our samples suggest that the AMS is dominated by Ti-magnetite (see Figure A3). The low degrees of anisotropy in our samples ( $\mathrm{Pj} 1.01$ to 1.04) may indicate that there are several competing ferrimagnetic components of the petrofabric contributing to the AMS fabric, such as the distribution and shape fabric of the Ti-magnetite or smaller SD magnetite [67-71]. The principal axes of the in-phase and out of phase AMS generally agree, although the distribution of the axes of individual sub-specimens in opAMS are more widely scattered (Figures A5 and A6). Interestingly, in a sample with oblate ipAMS, the opAMS may be prolate but the principal axes of the sub-specimens plot along the $\mathrm{k}_{1}$ and $\mathrm{k}_{2}$ girdle of ipAMS (Figures A5 and A6). The opAMS therefore reflect the fabric of smaller magnetite in the groundmass of the sample, which is essentially groundmass fabric [56,57]. Thus, the agreement of the ipAMS and opAMS suggest that the AMS fabric reflect the primary magmatic flow fabric of the dyke. See appendix B for a detailed discussion on the carriers of the AMS fabric in the Sosa dyke samples. 

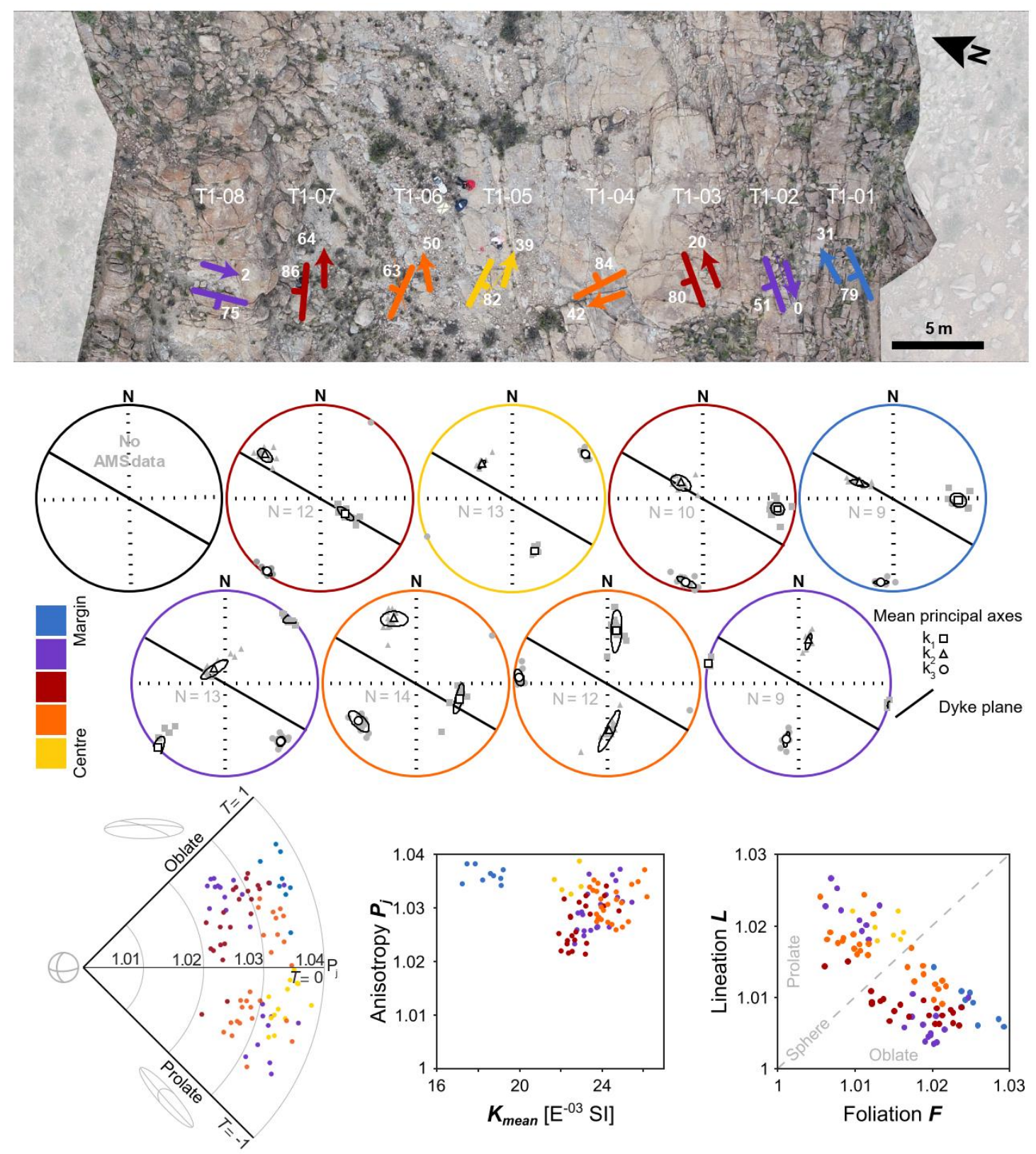

Figure 6. Sosa Dyke-Traverse T1 ipAMS. (Top row) Sample location of T1 across the Sosa Dyke (Figure 2), where the same sample locations were used for whole rock geochemistry samples (Table A1); Magnetic lineation (Arrows); Magnetic foliation (strike-dip symbols). (Middle row) ipAMS data; contour shows 95\% Jelinek confidence ellipse of mean principle tensor. (Lower row) ipAMS shape parameter plots. Samples from across the dyke displays varied fabric shapes, both transitional prolate and oblate. The AMS fabrics are oriented obliquely relative to the dyke margin. In the SW half of the dyke the foliation fabrics are dominantly oriented E-W. In the NE half of the dyke sample foliations dominantly strike NW-SE. 


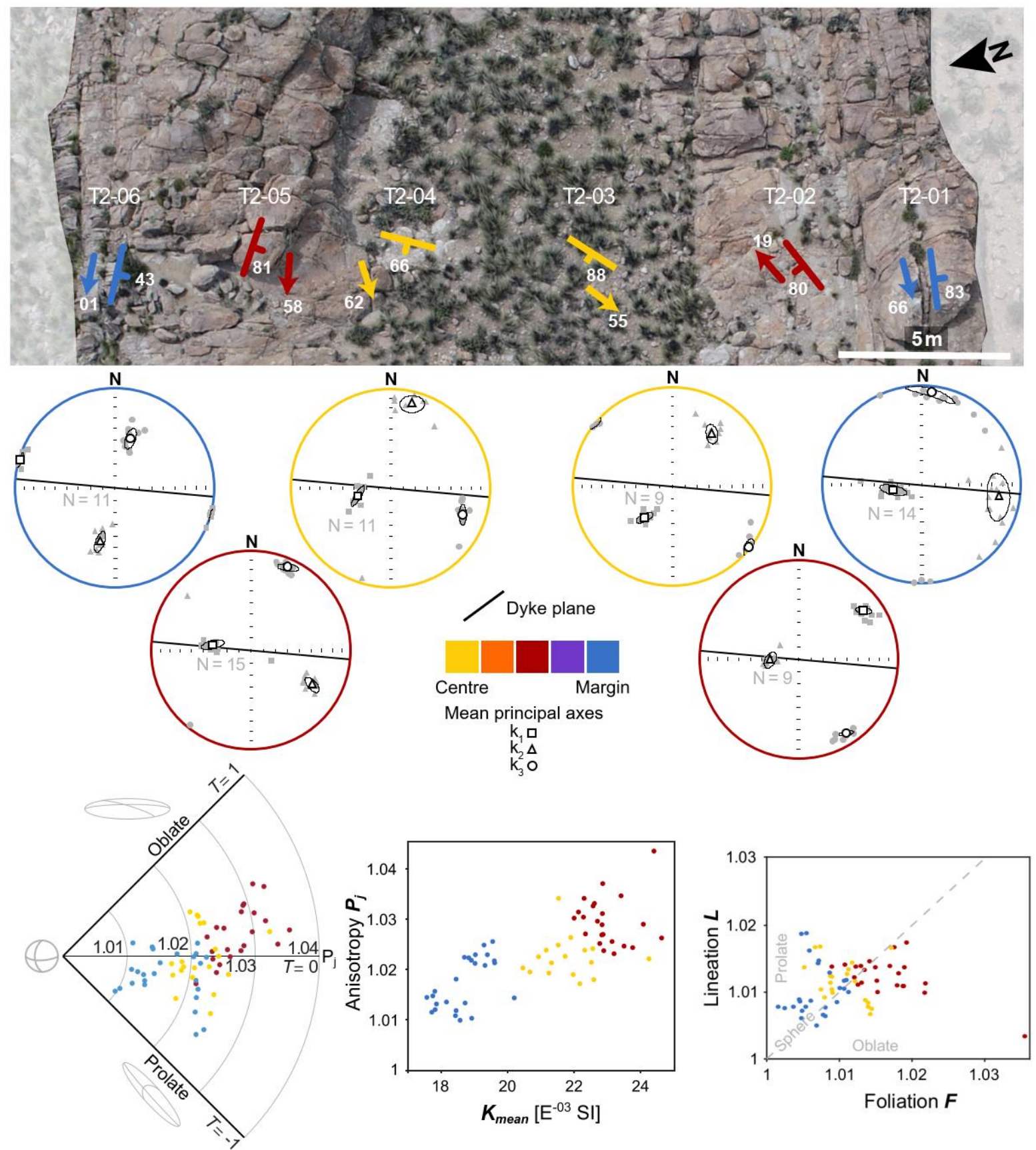

Figure 7. Sosa Dyke-Traverse T2 ipAMS. (Top row) Sample location of T2 (see Figure 2) The same sample locations were used for whole rock geochemistry samples (Table A1); Magnetic lineation (Arrows); Magnetic foliation (strike-dip symbols). (Middle row) ipAMS data; contour shows 95\% Jelinek confidence ellipse of mean principal tensor. (Lower row) Shape parameter plots. The marginal samples display a dominantly margin-parallel transitional prolate fabric. Samples from the interior of the dyke exhibit triaxial to transitional oblate fabrics oriented obliquely to the dyke margin.

\subsection{Geochemistry}

The results of the whole rock geochemistry from the sampled traverses T1 and T2 on the Sosa Dyke and the centre and margin samples of the Great Dyke show a trachyte/trachydacite composition. The Sosa Dyke samples display a more mafic composition for the centre parts of the dyke compared to the dyke margins (Figure 8; Tables A1 and A2). Rare earth element (REE) data and trace element data do not show any apparent differences between margin and centre of the dyke (Table A1). The sample GD-C6 of the Sosa dyke 
was taken in addition to a traverse close to one of the clast-filled veins and shows a lower alkali content than the rest of the samples (Table A2).

The whole rock composition of the Great Dyke is that of a trachyte/trachydacite. Notably, the centre sample shows the same composition as the Cerro Bayo cryptodome [49] (Figure 8), whereas the margin sample shows a composition similar to the Sosa Dyke.

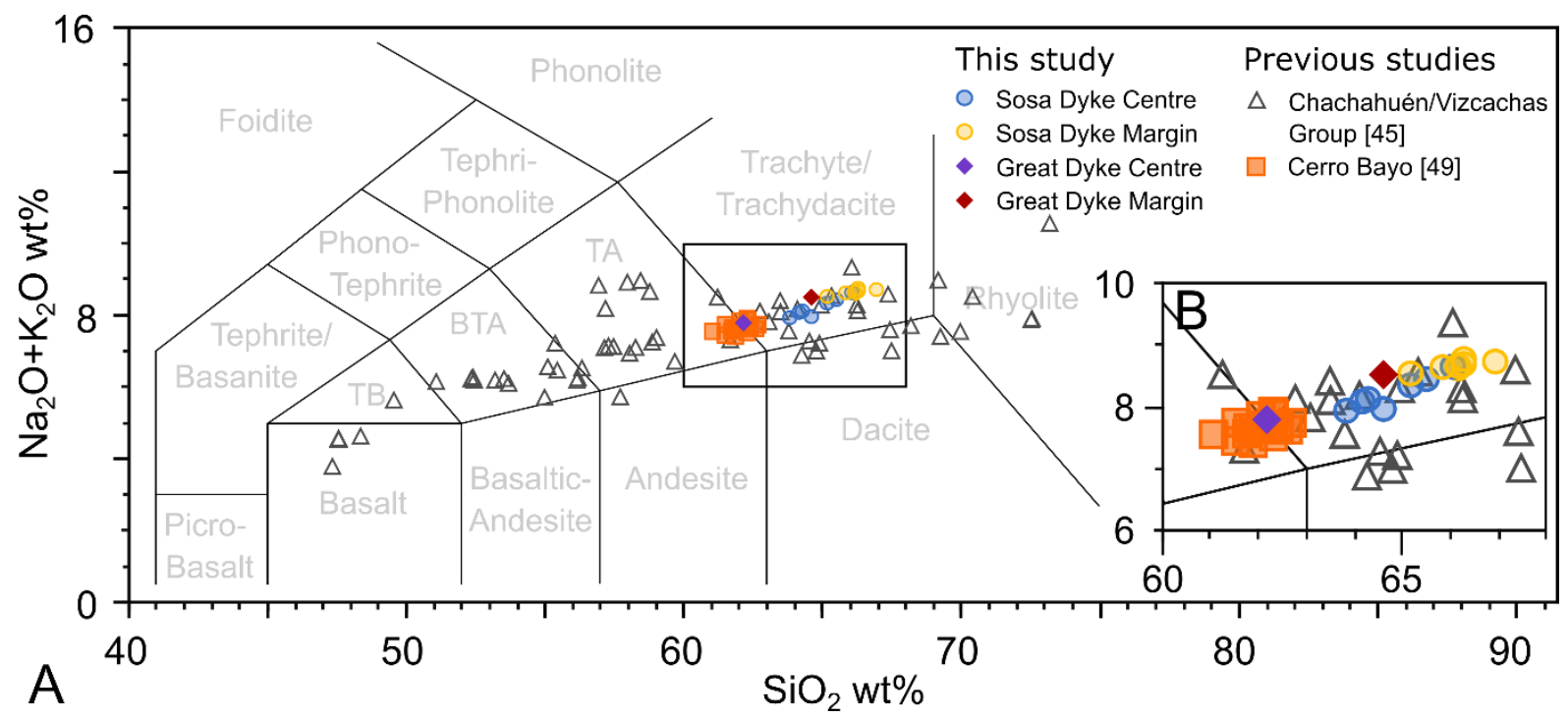

Figure 8. Classification of the Chachahuén rocks. (A) TAS-Diagram showing data from previous analysis and this study. (B) Zoom to of (A).

\subsection{Viscosity}

The whole rock geochemistry, total water content (FTIR), crystal content and crystal size (thin sections) from this study (Table 1) are combined with the temperature and pressure estimates from Burchardt et al. [49]. They obtained temperatures of $790{ }^{\circ} \mathrm{C}$ and $850{ }^{\circ} \mathrm{C}$ based on the lowest temperature estimates for plagioclase and amphibole crystallization, respectively. The pressure of $10 \mathrm{MPa}$ was estimated using the lithostatic pressure with an approximate emplacement depth of several hundred metres, derived from amphibole breakdown rims for the Cerro Bayo cryptodome [72]. Given the proximity of the Sosa Dyke and the Cerro Bayo (Figure 1), we used the same pressure estimate. These values of temperatures and pressure were used as input parameters for the MAGMA Version 2.50.0160 (Kware) software tool to calculate the viscosity of the two dykes. The results of this calculation provide an average effective viscosity of $\eta_{\text {eff }}$ of $2.42 \times 10^{6} \mathrm{~Pa} \cdot \mathrm{s}\left(790^{\circ} \mathrm{C}\right)$ and $1.17 \times 10^{6} \mathrm{~Pa} \cdot \mathrm{s}\left(850^{\circ} \mathrm{C}\right)$ for the Great Dyke and $5.20 \times 10^{6} \mathrm{~Pa} \cdot \mathrm{s}\left(790^{\circ} \mathrm{C}\right)$ and $2.54 \times 10^{6} \mathrm{~Pa} \cdot \mathrm{s}$ $\left(850^{\circ} \mathrm{C}\right)$ for the Sosa Dyke.

Table 1. Input parameters for MAGMA (Kware) viscosity calculator.

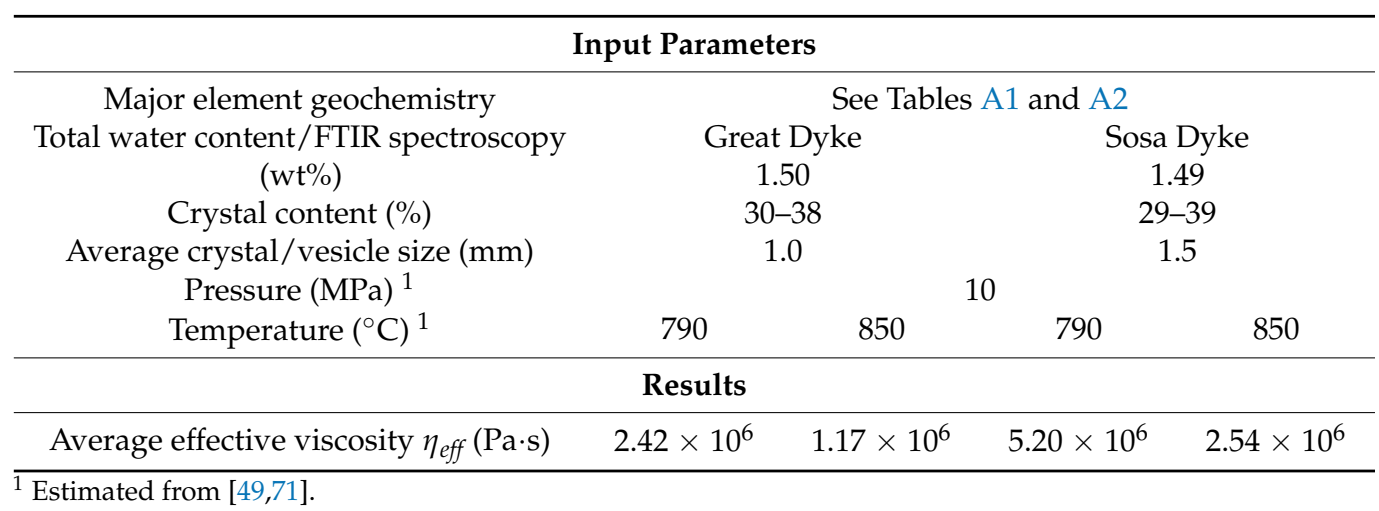




\section{Interpretation/Discussion}

\subsection{Segment Offset-Initial Dyke Geometry or Tectonic Feature?}

The interpreted orthophoto (Figure 2) displays a significant offset between segment II and III of the Sosa Dyke. Perez and Condat [48] interpreted the segment offset to be associated with a post-emplacement tectonic fault due to its alignment with large-scale regional lineaments in the area. However, the occurrence of a continuous chilled margin around both ends of segments II and III, which are related to the fast cooling (quenching) of hot magma in contact with a cold host rock during the initial phase of dyke emplacement [73], argues against faulting between the dyke segments. The absence of a chilled margin in contact with the host rock, i.e., along a fault plane, would indicate that the magma was already cooled down, and most likely solid, to accommodate the tectonic stresses in a brittle manner (fault). This shows, that the observation of offsets between segments alone is not conclusive evidence for faulting. Many field and seismic studies showcase step-features and segment offsets related to initial flow geometries $[21,25,28,35,74-76]$ rather than postemplacement tectonic events. The recent work by Galland et al. [27] explains that intrusion segment offsets can be easily misinterpreted as tectonic fault-related offsets rather than an intrusion emplacement feature. Thus, considering our detailed field observations (cf. Figure 1), we conclude that the segmented shapes of the dykes, including the long offset between segment II and III of the Sosa Dyke, are primary and related to the emplacement of the dykes, rather than to post-emplacement tectonic faulting.

\subsection{Interpretation of Magma Flow Direction in the Sosa Dyke}

Despite its large size, the Sosa Dyke does not show any internal borders, such as chilled margins or sudden changes in magma composition, i.e., hybridisation [77] or phenocryst content which would be indicative for its emplacement as a composite dyke [77-79]. Thus, we conclude that the Sosa Dyke was emplaced as one continuous flow rather than multiple successive flow injections.

The outcrop of the Sosa Dyke revealed zones of aligned crystals and mafic enclaves parallel to the strike of the dyke (Figure 3E), and oriented curved fractures across the dyke (Figures 2 and 3), both suggesting a lateral magma flow direction towards the East. An indepth analysis for magma flow related magmatic fabrics of our traverse T1 samples showed that the magnetic foliation strikes $\mathrm{E}-\mathrm{W}$ in the southern half of the dyke. In the northern half of the dyke, the magnetic foliation strikes NE-SW. In samples with dominantly prolate fabric (in the centre of the dyke), the lineation is sub-parallel to the strike of the dyke and dips moderately to the West (Figure 6). Overall the intersection between the steeplydipping magnetic foliations indicates a dominantly lateral flow direction towards NNE. In the traverse $\mathrm{T} 2$ samples, the magnetic fabric on the northern half of the dyke is steeply to moderately dipping and strikes WNW-ESE. On the southern half of the dyke, the magnetic foliation is steeply dipping and strikes NE-SW (Figure 7). The abundance of other studies showcase that AMS is a commonly used method to interpret the flow direction in dykes [33-35,53,78,80-82]. It is expected that the AMS in sheet intrusions are imbricated due to the interaction between the magma and the intrusion wall [33]. The intersection between the AMS fabric at the opposite walls of a sheet intrusion therefore reveals the magma flow vector. Thus, we conclude that the magma flow indicators in the Sosa Dyke record a dominantly lateral magma flow towards the East.

The lateral magma flow direction inferred from the AMS data is potentially in contradiction with the segment shape of the dykes. Segmentation of igneous sheet intrusions has been extensively documented through seismic data $([74,75,83]$ and references therein) and field observations ([25,27,29,83] and references therein), [84-86]. Segments are usually interpreted as magma flow indicators, as supported by (1) the three-dimensional shape of radial finger distribution on seismic data(e.g., [74,87], (2) structural field measurements indicating segment bridges are magma flow markers [27], and (3) laboratory experiments [88]. According to these studies, the segment geometry of the Sosa Dyke indicates a dominantly upward magma flow, which is contradictory with the AMS measurements that indicate 
overall lateral magma flow. One explanation of such a mismatch is that the segment geometry might indicate the overall magma propagation direction while AMS fabrics might indicate the stage of lateral inflation of the upward propagating finger [85], such as evidenced by laboratory experiments [89]. Alternatively, the works by Poland et al. [35], Townsend et al. [90], and Healy et al. [18] on mafic to felsic dykes show that dominant lateral magma flow can also result in dyke segment geometries similar to what was observed in this study. Further studies on changes in the magma flow direction during sheet propagation and subsequent magma transport through established sheets (e.g., [91]) is necessary to potentially solve the discrepancy between the observed dyke geometries and flow indicators.

\subsection{High-Viscosity Sheet Intrusions and the Effect of Different Host Rocks on the Intrusion Geometry}

We first verify that the Sosa and Great Dyke are good examples for the geometries of thick, high-viscous magmatic sheets. Therefore, we compare the overall dyke geometry, represented by the maximum thickness and length values, with other examples of highviscous sheet intrusions in the world. The $67 \mathrm{~m}$ thickness $/ 1300 \mathrm{~m}$ length and $39 \mathrm{~m}$ thickness $/ 2000 \mathrm{~m}$ length, for the Sosa and Great Dyke, respectively, are a good match with the well-studied high-viscosity silicic dykes from Summer Coon volcano in Colorado/USA (50 $\mathrm{m}$ thickness /2000-7000 $\mathrm{m}$ length; e.g., [35,92] and references therein). In addition, the dimensions and field observations of the Sosa and Great Dyke are in agreement with the data collection by Cruden et al. [2], plotting in between long mesoscale sheets and thin laccolith. Thus, we conclude that the Sosa and Great Dyke are valid representatives of commonly known, thick, high-viscosity dykes/(sub-)vertical sheet intrusions.

To further strengthen the representativity of the Sosa and Great Dyke, we calculated the effective viscosities for each sample, which are on the order of $\sim 10^{6} \mathrm{~Pa} \cdot \mathrm{s}$ for both the Sosa Dyke and the Great Dyke. This places the Sosa and Great Dyke well in the range of viscosities for intermediate- to high-viscosity magmas $\left(10^{4}\right.$ to $\left.10^{8} \mathrm{~Pa} \cdot \mathrm{s}\right)$ with a phenocryst content of up to $50 \%$ (e.g., $[93,94])$. It is important to note that the calculated viscosities provide only a bulk value for the magma viscosities in the Sosa and Great Dyke, whether viscosity changed spatially (position in the dyke) and with time (initial intrusion to final solidification) cannot be resolved.

Magma viscosity is only one important parameter that affects the geometry of the Sosa and Great Dyke, another one is the host rock they are emplaced in. Our field observations show that both the Sosa and the Great Dyke emplaced into various host rocks, i.e., basaltic lavas, block and ash flows, of different mechanical strengths (e.g., [95]) without a systematic change in dyke geometry (Figures 2, 5 and 9). This suggests that host rock lithology and strength play a minor role during the emplacement of the studied dykes. This is in contrast to the findings of recent field studies $[21,27,96]$ and laboratory/numerical modelling studies [37,97-102], which associate mechanically different host rock types with different intrusion geometries. Recent studies e.g., $[95,103,104]$ show that the variation in mechanical strength between different rock types is commonly smaller than one order of magnitude. Hence, the range of host rock strengths is significantly smaller than the range of magma viscosities observed in nature, which can easily vary by six orders of magnitude $\left(10^{2}\right.$ to $\left.10^{8} \mathrm{~Pa} \cdot \mathrm{s}\right)[93,105]$ or more [106]. The models of e.g., Galland et al. [99] and Schmiedel et al. [98] suggest that the emplacement of magma is governed not only by the magma viscosity or the host rock strength, but by the balance between the viscous stresses within the flowing magma and the deforming host rock. Given the high viscosity of the magma emplaced in the Sosa and Great Dykes, these models propose that the viscous stresses within the magma dominate the emplacement of the dykes over the host rock properties.

\subsection{Segment Geometry and Dyke Emplacement}

Dyke segment tips are often used to infer the model of emplacement e.g., the linear elastic fracture mechanics model (LEFM), viscous indenter model, etc., correlated to magma viscosity and host rock strength (e.g., [22,36,107]). The tips of the segments of the Sosa and 
Great Dyke tend to be oval (Figure 9). The comparison of segment geometry data from this study with data of other sheet intrusion segments with viscosities ranging from lowviscosity dykes (mafic; $[21,25,28]$ ) to intermediate/high-viscosity sills [27] does not allow for a distinction in segment (tip) shape towards our high-viscosity dykes. Furthermore, even though the sheet intrusion data sets record magma emplacement into various host rocks, no correlation between host rock type and sheet segment geometry is apparent. These results question the common practice of using dyke segment geometries as proxy for a single intrusion emplacement mechanism (cf. $[28,40])$. In order to reveal the emplacement and propagation mechanism, it is therefore necessary to also describe the host rock structures associated with the creation of space for the magma $[26,27,36]$.

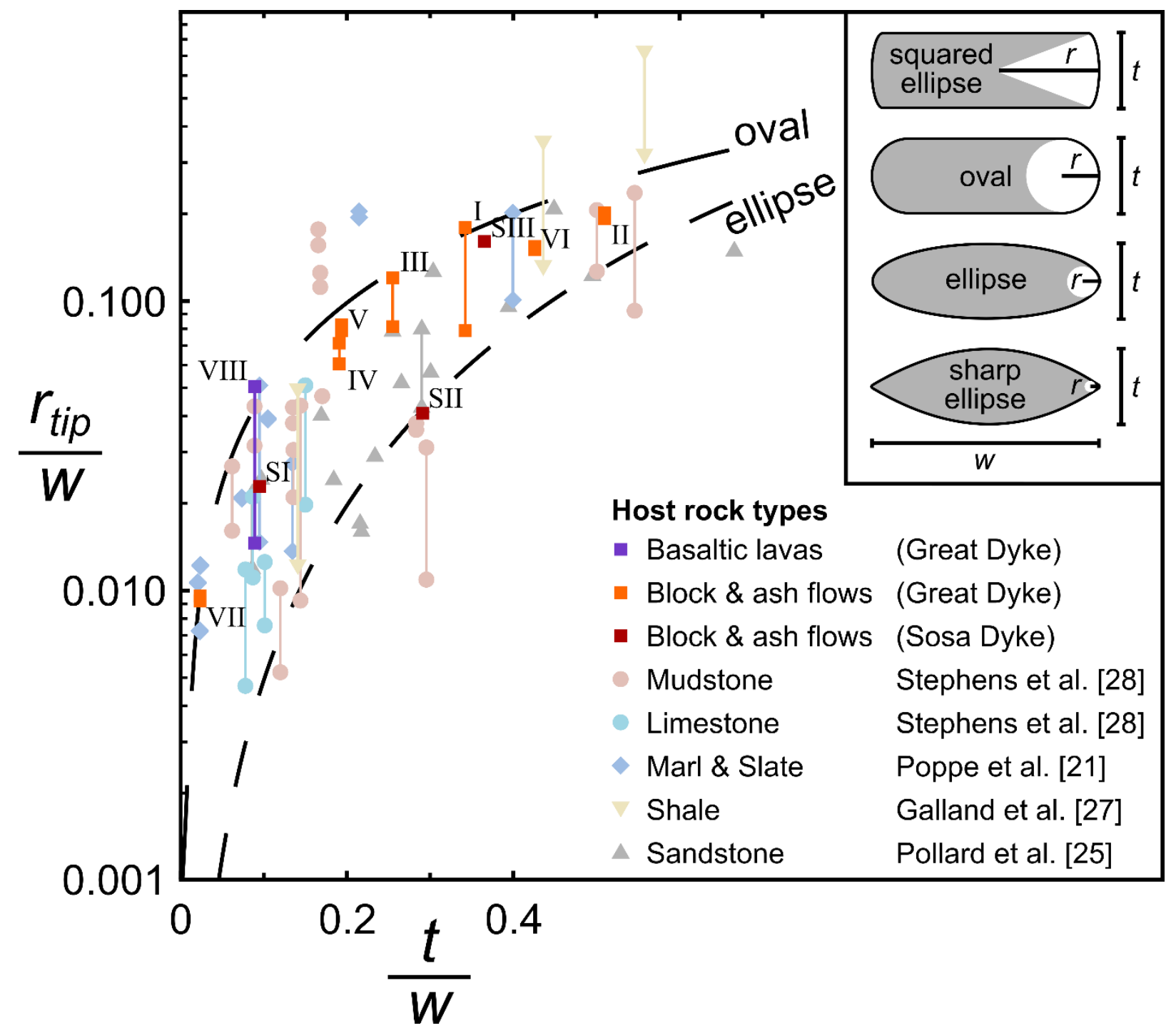

Figure 9. Dyke segment geometries. The plot is redrawn and modified after Pollard et al. [25] and Stephens et al. [28]; squares represent data from this study. Roman numbers correspond to the segments of the Sosa Dyke (SI-SIII) and the Great Dyke (I-VIII) in Figures 2 and 4, respectively (Data: Appendix C). Colours represent different host rocks. The vertical line indicates two data points belong to the same segment (e.g., left and right tip of a segment); no line, means only one data point (tip) was observed for that segment. $t$-segment thickness, $w$-segment width, $r_{\text {tip }}$-radius of segment tip curvature. (inset) Schematic simplification of the different types of observed intrusion segment shapes and their parameters; squared ellipses can be expected in the plot above the "oval" line, whereas sharp ellipse shapes are displayed below the "ellipse" line.

A challenge of interpreting the shapes of segment and their tips in terms of magma emplacement is that outcrops offer the end-product of a complex, potentially multi-stage 
phenomenon. Stephens et al. [28] propose that distinct intrusion segment geometries can represent successive stages during the emplacement of a sheet intrusion rather than showcasing distinct emplacement mechanisms: (1) initiation: segments thin tapered tips (Mode I, tensile opening), which later on can be transformed into (2) oval/squared ellipse tip shapes (inelastic deformation or viscous indenter model), governed by the magma viscosity and host rock strength. These authors only tested their model on outcrops of low-viscosity sheet intrusions. The newly acquired data sets from this study seem to corroborate their "multistage-model" also in the range of high-viscosity sheet intrusions (Figure 9). Even if the multistage model seems to fit most of the field observations of the data sets investigated (see Figure 9 for references) it remains unclear if the proposed order of stages is always the same. The elasto-plastic, analytical model of Scheibert et al. [108] for example suggests the opposite, i.e., a more prominent inelastic deformation during the earlier stage of emplacement.

A key observation on the Sosa and Great Dyke is that the walls of each segment are (sub-)parallel, i.e., each segment exhibits a relatively constant thickness along-strike, except close to the tips. This shape is really similar to those of igneous fingers described by Spacapan et al. [26], who show that their entire emplacement was accommodated by pushing of the host rock entirely without Mode I opening. Moreover, the parallel-wall shape is also very similar to the laboratory viscoelastic fingers of Bertelsen et al. [32], which are emplaced in relatively weak host matrix. Conversely, the laboratory intrusions of Bertelsen et al. [32] into stronger host rock exhibit tapered shapes only at the end of the experiments. This discussion highlights that the final intrusion shape is not sufficient to reveal the entire emplacement history of magmatic sheet intrusions. One potential solution to overcome this limitation could be to better integrate rock physical methods into models for magma emplacement aided by detailed field observations of rock failure mechanisms and structures in magma and host rock, which would enable the performance of a time-resolved, quantitative structural back restoration.

\section{Conclusions}

Our field observations on the geometry of the two exceptionally well exposed magmatic sheets: the Sosa Dyke and the Great Dyke, in the Miocene Chachahuén volcano in Argentina combined with magma flow indicators (fractures, crystals, AMS) within the dykes, and their calculated magma viscosity lead us to conclude that:

- The segment geometries observed in this study are related to the emplacement of the dykes, rather than the result of post-emplacement tectonic deformation;

- AMS and curved fractures record a dominant lateral magma flow direction in the Sosa Dyke towards the East, thus contradicting expected vertical magma flow derived from dyke segment geometry. It remains unsolved if the flow indicators thus record a late-stage of a dominantly vertical dyke emplacement or an overall lateral dyke emplacement;

- The comparison between low- to high-viscosity magma sheet segment geometries reveal a significant similarity. Thus, we question the common practice of using sheet segment geometries as proxies for different intrusion emplacement mechanisms of low- and high-viscosity sheet intrusions;

- The similarities between low- and high-viscosity sheets emplaced within host rocks of different strengths suggest that magma sheet emplacement is governed not only by the magma viscosity or the host rock strength, but by the balance between the viscous stresses within the flowing magma and the deforming host rock. The final intrusion shape is not sufficient to reveal the entire emplacement history of magmatic sheet intrusions.

To overcome the limitation of field observations as the final snapshot of an intrusion emplacement history, future work should concentrate on the time-resolution during magma emplacement of potentially various different emplacement mechanisms. One potential solution could be the better integration of rock physical methods into models for magma 
emplacement aided by detailed field observations of rock failure mechanisms and structures in both magma and host rock. This would help with the undertaking of a quantitative back restoration of structures and related processes and thus help to improve current geophysical and geodetic models for eruption forecasts. In addition, for the growing field of planetary volcanology with surface imagery as the main data source, we need a solid understanding of related magma transport in the subsurface to be able to interpret extra-terrestrial processes e.g., [109].

Supplementary Materials: The following are available online at https: / www.mdpi.com/article/10 $.3390 / \min 11101113 / \mathrm{s} 1$, Magnetic data.xlsx and MAGMArecord.zip. The Matlab code and data used for the segment geometries are available under: https:/ / doi.org/10.5281/zenodo.4784164.

Author Contributions: Conceptualization, T.S. and S.B.; methodology, T.S., S.B., F.G., T.M., J.O.P., O.G. and H.S.; software, T.S., F.G. and T.M.; validation, T.S., S.B., T.M., F.G. and O.G.; formal analysis, T.S., S.B., T.M., H.S.; investigation, T.S., S.B., T.M. and F.G.; resources, T.S., S.B., T.M., H.S. and F.G.; data curation, T.S., S.B., T.M. and F.G.; writing-original draft preparation, T.S., S.B., O.G., T.M., F.G., J.O.P. and H.S.; writing-review and editing, T.S., S.B., O.G., T.M., J.O.P., F.G. and H.S.; visualization, T.S., S.B., T.M.; supervision, T.S., S.B.; project administration, S.B.; funding acquisition, S.B. All authors have read and agreed to the published version of the manuscript.

Funding: This project and Tobias Schmiedel are funded by the Knut and Alice Wallenberg Foundation through a Wallenberg Academy Fellow grant to Steffi Burchardt (grant No. KAW 2017.0153).

Data Availability Statement: The Matlab code and data used for the segment geometries are available under: https:/ / doi.org/10.5281/zenodo.4784164. The 3D models of the Sosa Dyke and Great Dyke are available via https:/ /v3geo.com/model/273 and https://v3geo.com/model/272, respectively. To access the thin sections and remaining rock sample materials please contact Steffi Burchardt at MPT, Department of Earth Sciences at Uppsala University.

Acknowledgments: The authors are grateful for the field assistance, hospitality and help from the Sosa family and Rubén Castillo. We thank Sam Poppe and Tara Stephens for easy access to background information on their published data. Moreover, we are grateful for the support from Emma Rhodes, Hélène Breton, and Bjarne Almqvist with sample preparation, software and equipment at Uppsala University. Comments from participants of the LASI IV conference, as well as discussions with Taylor Witcher and Christoph Hieronymus have helped to develop the contents presented in this manuscript. The Swedish Geological Survey is acknowledged for facilitating core drilling of samples. The authors acknowledge the use of the Move Software Suite granted by Petroleum Experts academic software initiative. We thank Simon Buckley and Conor Lewis from the Virtual Outcrop Geology Group (VOG Group) for the fast and uncomplicated publication of our 3D outcrop models on their platform V3Geo (https://v3geo.com/, accessed on 4 October 2021).

Conflicts of Interest: The authors declare no conflict of interest.

Appendix A. Whole Rock Geochemistry and Fourier Transform Infrared Spectroscopy (FTIR) Analysis

\section{Appendix A.1. Whole Rock Geochemistry}

Table A1. Whole-rock major ( $\mathrm{wt} \%$ ) and trace element (ppm) ICP analyses of samples from the Sosa dyke traverse $\mathrm{T} 1$ for sample locations see Figure 6.

\begin{tabular}{cccccccccc}
\hline & \multicolumn{1}{c}{ Sosa Dyke (GD) } \\
\hline SAMPLE & T1-01 & T1-02 & T1-03 & T1-04 & T1-05 & T1-06 & T1-07 & T1-08 & T1-09 \\
\hline $\mathrm{SiO}_{2}(\mathrm{wt} \%)$ & 64.7 & 65.1 & 64.1 & 63.2 & 63.6 & 62.9 & 63.3 & 64.1 & 65.0 \\
$\mathrm{Al}_{2} \mathrm{O}_{3}$ & 17.60 & 17.75 & 17.60 & 17.30 & 17.40 & 17.25 & 17.45 & 17.85 & 17.80 \\
$\mathrm{Fe}_{2} \mathrm{O}_{3}$ & 3.35 & 3.32 & 3.48 & 3.57 & 3.33 & 3.23 & 3.38 & 3.38 & 3.56 \\
$\mathrm{CaO}$ & 4.07 & 3.56 & 3.67 & 3.37 & 3.24 & 4.40 & 3.39 & 3.38 & 3.70 \\
$\mathrm{MgO}$ & 0.78 & 0.61 & 0.72 & 0.73 & 0.82 & 0.78 & 0.66 & 0.61 & 0.68 \\
$\mathrm{Na}_{2} \mathrm{O}$ & 5.03 & 4.95 & 4.81 & 4.55 & 4.45 & 4.47 & 4.66 & 4.85 & 4.89 \\
\hline
\end{tabular}


Table A1. Cont.

\begin{tabular}{|c|c|c|c|c|c|c|c|c|c|}
\hline \multirow[b]{2}{*}{ SAMPLE } & \multicolumn{9}{|c|}{ Sosa Dyke (GD) } \\
\hline & T1-01 & T1-02 & T1-03 & T1-04 & T1-05 & T1-06 & T1-07 & T1-08 & T1-09 \\
\hline $\mathrm{K}_{2} \mathrm{O}$ & 3.39 & 3.52 & 3.35 & 3.38 & 3.37 & 3.33 & 3.31 & 3.48 & 3.55 \\
\hline $\mathrm{Cr}_{2} \mathrm{O}_{3}$ & $<0.002$ & $<0.002$ & $<0.002$ & $<0.002$ & $<0.002$ & $<0.002$ & $<0.002$ & $<0.002$ & $<0.002$ \\
\hline $\mathrm{TiO}_{2}$ & 0.42 & 0.41 & 0.41 & 0.43 & 0.41 & 0.41 & 0.42 & 0.41 & 0.41 \\
\hline $\mathrm{MnO}$ & 0.17 & 0.13 & 0.15 & 0.19 & 0.08 & 0.13 & 0.11 & 0.12 & 0.17 \\
\hline $\mathrm{P}_{2} \mathrm{O}_{5}$ & 0.12 & 0.14 & 0.14 & 0.15 & 0.13 & 0.14 & 0.15 & 0.14 & 0.15 \\
\hline $\mathrm{SrO}$ & 0.11 & 0.10 & 0.10 & 0.09 & 0.09 & 0.09 & 0.10 & 0.10 & 0.10 \\
\hline $\mathrm{BaO}$ & 0.13 & 0.13 & 0.13 & 0.13 & 0.12 & 0.12 & 0.12 & 0.13 & 0.13 \\
\hline LOI & 1.20 & 1.07 & 1.56 & 2.29 & 2.94 & 3.62 & 2.36 & 1.34 & 1.15 \\
\hline Total & 101.07 & 100.79 & 100.22 & 99.38 & 99.98 & 100.87 & 99.41 & 99.89 & 101.29 \\
\hline $\mathrm{Ba}(\mathrm{ppm})$ & 1120 & 1095 & 1100 & 1105 & 1050 & 1060 & 1060 & 1110 & 1150 \\
\hline $\mathrm{Ce}$ & 79.9 & 78.2 & 76.6 & 79.4 & 71.7 & 76.5 & 82.0 & 77.1 & 80.0 \\
\hline $\mathrm{Cr}$ & $<10$ & $<10$ & $<10$ & $<10$ & $<10$ & $<10$ & $<10$ & $<10$ & $<10$ \\
\hline Cs & 10.20 & 4.25 & 4.27 & 4.47 & 4.48 & 4.30 & 4.07 & 4.15 & 5.44 \\
\hline Dy & 3.99 & 3.94 & 3.84 & 4.57 & 3.47 & 4.35 & 4.17 & 3.87 & 3.98 \\
\hline $\mathrm{Er}$ & 2.43 & 2.34 & 2.34 & 2.82 & 2.06 & 2.71 & 2.46 & 2.36 & 2.42 \\
\hline $\mathrm{Eu}$ & 1.74 & 1.65 & 1.65 & 1.82 & 1.57 & 1.66 & 1.78 & 1.78 & 1.73 \\
\hline $\mathrm{Ga}$ & 21.7 & 21.1 & 21.0 & 21.6 & 21.0 & 20.2 & 20.9 & 21.2 & 21.5 \\
\hline $\mathrm{Gd}$ & 5.10 & 4.64 & 4.69 & 5.40 & 4.12 & 5.17 & 4.99 & 4.73 & 4.77 \\
\hline Hf & 5.5 & 5.6 & 5.0 & 5.2 & 5.5 & 5.1 & 5.1 & 6.1 & 5.5 \\
\hline Ho & 0.82 & 0.77 & 0.80 & 0.92 & 0.69 & 0.88 & 0.85 & 0.78 & 0.79 \\
\hline $\mathrm{La}$ & 41.5 & 41.2 & 40.4 & 42.6 & 38.7 & 40.3 & 43.6 & 40.8 & 42.7 \\
\hline $\mathrm{Lu}$ & 0.43 & 0.41 & 0.41 & 0.49 & 0.39 & 0.46 & 0.43 & 0.46 & 0.45 \\
\hline $\mathrm{Nb}$ & 18.1 & 17.3 & 17.0 & 17.9 & 16.5 & 17.0 & 18.0 & 17.5 & 17.3 \\
\hline $\mathrm{Nd}$ & 33.4 & 32.6 & 32.2 & 34.7 & 30.2 & 32.7 & 34.7 & 32.0 & 32.6 \\
\hline $\operatorname{Pr}$ & 9.30 & 8.84 & 8.88 & 9.36 & 8.46 & 8.98 & 9.54 & 8.94 & 9.23 \\
\hline $\mathrm{Rb}$ & 166.0 & 172.5 & 162.5 & 169.0 & 166.5 & 165.5 & 165.5 & 173.0 & 177.5 \\
\hline $\mathrm{Sm}$ & 6.25 & 5.80 & 5.89 & 6.45 & 5.48 & 6.17 & 6.30 & 5.90 & 5.98 \\
\hline Sn & 1 & 1 & 1 & 1 & 1 & 1 & 1 & 1 & 1 \\
\hline $\mathrm{Sr}$ & 949 & 875 & 863 & 798 & 762 & 771 & 831 & 857 & 876 \\
\hline $\mathrm{Ta}$ & 1.2 & 1.1 & 1.1 & 1.1 & 1.0 & 1.1 & 1.1 & 1.1 & 1.1 \\
\hline $\mathrm{Tb}$ & 0.70 & 0.67 & 0.72 & 0.75 & 0.58 & 0.71 & 0.73 & 0.67 & 0.70 \\
\hline Th & 11.45 & 11.05 & 10.80 & 11.00 & 10.70 & 10.65 & 10.95 & 11.25 & 11.25 \\
\hline $\mathrm{Tm}$ & 0.40 & 0.38 & 0.39 & 0.40 & 0.35 & 0.44 & 0.40 & 0.37 & 0.36 \\
\hline $\mathrm{U}$ & 3.73 & 3.82 & 3.64 & 3.63 & 3.46 & 3.47 & 3.51 & 3.77 & 3.93 \\
\hline $\mathrm{V}$ & 31 & 34 & 31 & 34 & 32 & 30 & 32 & 32 & 32 \\
\hline W & 140 & 63 & 63 & 76 & 50 & 57 & 44 & 43 & 54 \\
\hline $\mathrm{Y}$ & 24.4 & 23.0 & 23.2 & 27.7 & 20.8 & 27.2 & 24.4 & 23.3 & 23.4 \\
\hline $\mathrm{Yb}$ & 2.68 & 2.69 & 2.70 & 3.00 & 2.45 & 2.90 & 2.77 & 2.62 & 2.77 \\
\hline $\mathrm{Zr}$ & 253 & 239 & 224 & 230 & 247 & 222 & 220 & 278 & 244 \\
\hline
\end{tabular}

Table A2. Whole-rock major ( $\mathrm{wt} \%$ ) ICP analyses of samples from the Sosa dyke traverse T2 (for sample locations see Figures 2 and 7) and the Great Dyke (sample locations Figure 4).

\begin{tabular}{ccccccccc}
\hline & \multicolumn{3}{c}{ Sosa Dyke (GD) } & \multicolumn{3}{c}{ Great Dyke (CD) } \\
\hline SAMPLE & $\mathbf{T 2 - 0 1}$ & $\mathbf{T 2 - 0 2}$ & $\mathbf{T 2 - 0 3}$ & $\mathbf{T 2 - 0 4}$ & T2-06 & C6 & M1 & C1 \\
\hline $\mathrm{SiO}_{2}\left(\mathrm{wt}_{0}\right)$ & 65.7 & 65.0 & 64.4 & 64.9 & 65.1 & 62.4 & 61.4 & 63.6 \\
$\mathrm{Al}_{2} \mathrm{O}_{3}$ & 17.90 & 17.90 & 17.65 & 17.90 & 18.00 & 17.80 & 17.90 & 17.75 \\
$\mathrm{Fe}_{2} \mathrm{O}_{3}$ & 3.21 & 3.36 & 3.51 & 3.22 & 3.34 & 5.00 & 4.98 & 4.01 \\
$\mathrm{CaO}$ & 3.49 & 3.45 & 3.53 & 3.54 & 3.64 & 4.67 & 4.90 & 4.30 \\
$\mathrm{MgO}$ & 0.51 & 0.59 & 0.59 & 0.64 & 0.62 & 1.27 & 1.24 & 1.03 \\
$\mathrm{Na}_{2} \mathrm{O}$ & 4.86 & 4.95 & 4.92 & 4.96 & 4.96 & 3.89 & 4.31 & 4.62 \\
$\mathrm{~K}_{2} \mathrm{O}$ & 3.64 & 3.46 & 3.33 & 3.47 & 3.58 & 2.37 & 3.36 & 3.70 \\
$\mathrm{Cr}_{2} \mathrm{O}_{3}$ & $<0.002$ & $<0.002$ & $<0.002$ & $<0.002$ & $<0.002$ & 0.003 & $<0.002$ & $<0.002$ \\
$\mathrm{TiO}_{2}$ & 0.40 & 0.41 & 0.43 & 0.39 & 0.43 & 0.71 & 0.59 & 0.46 \\
$\mathrm{MnO}$ & 0.08 & 0.10 & 0.10 & 0.13 & 0.10 & 0.04 & 0.12 & 0.16 \\
$\mathrm{P}_{2} \mathrm{O}$ & 0.13 & 0.11 & 0.13 & 0.15 & 0.15 & 0.34 & 0.34 & 0.22 \\
$\mathrm{SrO}$ & 0.11 & 0.11 & 0.11 & 0.11 & 0.11 & 0.11 & 0.10 & 0.10 \\
$\mathrm{BaO}$ & 0.13 & 0.13 & 0.13 & 0.13 & 0.13 & 0.10 & 0.11 & 0.12 \\
$\mathrm{LOI}$ & 1.50 & 1.65 & 1.68 & 1.92 & 1.29 & 2.90 & 2.08 & 0.60 \\
$\mathrm{Total}$ & 101.66 & 101.22 & 100.51 & 101.46 & 101.45 & 101.60 & 101.43 & 100.67 \\
\hline
\end{tabular}


Appendix A.2. FTIR-Analysis
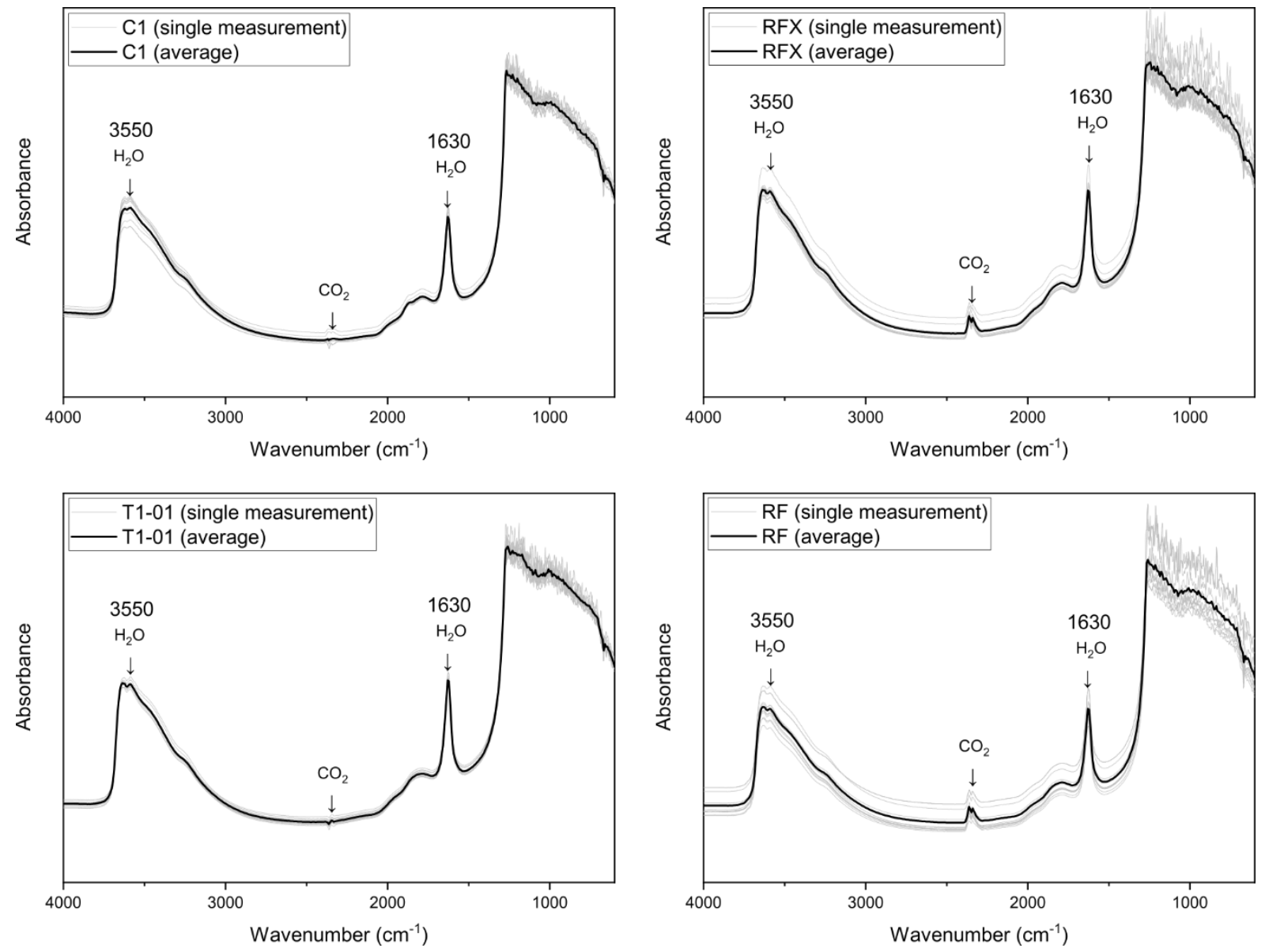

Figure A1. Absorbance spectra of all four analysed samples. Please note that RF and RFX were used only as control measurements and combined under RF in the next figure.

The results for both of the tested FTIR models to determine the total $\mathrm{H}_{2} \mathrm{O}$-content from the glass phase in the thick section samples are in general higher than the LOI values determined through whole rock geochemistry. In detail, for the Great Dyke the total $\mathrm{H}_{2} \mathrm{O}$-content calculated by the FTIR single extinction coefficient model shows an on average a $112 \%$ higher value for the total water content compared to the LOI value determined by the whole rock geochemistry $(0.6 \mathrm{wt} \%$; Figure A2). For the FTIR endmember extinction coefficient model, using two different extinction coefficients for molecular water and for the hydroxyl groups, we see an on average $150 \%$ higher value of total $\mathrm{H}_{2} \mathrm{O}$-content compared to the LOI value. In case of the Sosa Dyke, the determined values for water are minimally higher (3\%) for the FTIR single extinction coefficient model and $24 \%$ higher for the FTIR endmember extinction model compared to the values derived from whole rock geochemistry (Figure A2). 


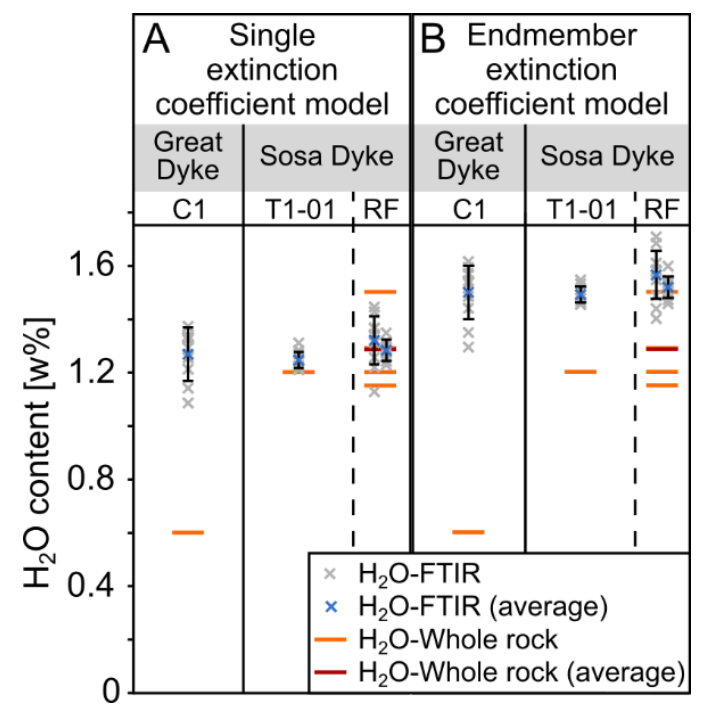

Figure A2. Water content FTIR and whole rock geochemistry. (A) Single $\mathrm{H}_{2} \mathrm{O}$ extinction coefficient model $\varepsilon \mathrm{H}_{2} \mathrm{O} 3550$ averaged values from [61]; (B) FTIR $\mathrm{H}_{2} \mathrm{O}$ endmember extinction coefficient $(\varepsilon)$ model using differentiated $\varepsilon \mathrm{H}_{2} \mathrm{O} 3550$ and $\varepsilon \mathrm{OH} 3550$ values from [62,63]; Whole rock geochemistry values are the same in both cases see Tables A1 and A2. The black error bars are marking the standard deviation determined from the 10 different measurements. RF-Reference samples to test repeatability of the FTIR measurements.

Appendix A.3. Point Counting (Crystal Content)

Table A3. Point counting results from thin sections.

\begin{tabular}{ccc}
\hline Samples & Total Points Counted & Crystal Content (\%) \\
\hline & Great Dyke & \\
M1 & 333 & 29.4 \\
C1 & 286 & 30.1 \\
& Sosa Dyke & \\
T1-01 & 336 & 36.9 \\
T1-02 & 320 & 35.0 \\
T1-05 & 310 & 35.5 \\
T1-09 & 312 & 37.5 \\
T2-03 & 322 & 39.1 \\
T2-06 & 293 & 35.5 \\
\hline
\end{tabular}

\section{Appendix B. Characterisation of AMS Carriers in the Sosa Dyke Rocks}

The temperature vs. susceptibility (T- $\chi$ ) experiments of the Sosa dyke samples reveal an initial increase in magnetic susceptibility to between 600 to $700 \times 10^{-6} \mathrm{SI}$ at $290{ }^{\circ} \mathrm{C}$. Subsequently the susceptibility decreases to about 400 to $500 \times 10^{-6}$ SI at 450 to $500{ }^{\circ} \mathrm{C}$ where the decrease is briefly levelling off before the susceptibility again drops more rapidly (Figure A3). Several of the samples from the interior of the dykes display an additional bump in the T- $\chi$ susceptibility curve at about $200 \times 10^{-6}$ SI between 600 to $620^{\circ} \mathrm{C}$. During cooling, the samples display a slow increase in susceptibility to $600{ }^{\circ} \mathrm{C}$ when the susceptibility starts to increase more rapidly until $500{ }^{\circ} \mathrm{C}$, after which the increase levels of. The bulk susceptibility of the samples of the Sosa dyke at room temperature are up to $90 \%$ lower after cooling compared to before heating (Figure A3). The presence of low Ti-Magnetite in the samples is indicated by the observed drop in susceptibility of around $\sim 550{ }^{\circ} \mathrm{C}$ [110], whereas the presence of Maghemite is indicated by the bump in the heating curve at around $300{ }^{\circ} \mathrm{C}$ [111-113]. The non-reversable behaviour of the samples during heating and cooling indicate that Ti-Magnetite partially altered to Ti-Maghemite is the main magnetic phase 
in the samples [cf. 112]. Furthermore, the decrease in susceptibility recorded in samples T1-04 to T1-06 at temperatures higher than $600{ }^{\circ} \mathrm{C}$ could indicate either the presence of Ti-Maghemite or Ti-Hematite [112]. The alteration of maghemite during heating explains why the magnetic susceptibility curves are non-reversable during cooling [111]

The interior of the Great dyke displays a similar T- $\chi$ curve as the Sosa dyke. The samples from the margin of the dyke, on the other hand, lack a distinct Maghemite bump in the heating curve. However, a small bump can be observed (Figure A3). During cooling, the susceptibility increases rapidly from $<100 \times 10^{-6} \mathrm{SI}$ at $600^{\circ} \mathrm{C}$ to $980 \times 10^{-6} \mathrm{SI}$ at $420^{\circ} \mathrm{C}$ before steadily decreasing to $50^{\circ} \mathrm{C}$. The cooling curve indicates the presence of Ti-rich magnetite or Ti-Hematite formed during the heating experiment [112,114].

NRM AF demagnetisation of selected sub-specimens from the Sosa dyke show a different demagnetisation response for traverses T1 and T2. Samples from traverse T1 display a gradual decrease in magnetization. About $50 \%$ of the magnetization is lost in fields in between 30 to $50 \mathrm{mT}$. Subsequently, the magnetization linearly decreases until $200 \mathrm{mT}$. Samples from traverse T2 lose $80 \%$ of their magnetization in an applied magnetic field below $40 \mathrm{mT}$ before the magnetization lies mostly constant with the increasing field. The samples of traverse $\mathrm{T} 1$ of the Sosa dyke indicate the presence of a magnetic mineralogy that contain both low and high coercivity phases. The high coercivity phase is likely the Tihematite that is indicated by the T- $\chi$ experiments. ARM acquisition was also performed on the sub-specimens (Figure A4). All samples are $90 \%$ saturated by an AC field of between 30 and $50 \mathrm{mT}$. The ARM magnetization shows that magnetite is the main remanence carrying grain that is picked up with AARM and AIRM measurement in the specimens.

Ti-Maghemite forms during subaerial (or near surface) low-temperature alteration of Ti-magnetite and can be altered to Ti-Hematite during heating [114]. The presence of Ti-hematite in the samples therefore suggest a shallow emplacement depth leading to an oxidizing environment of the magma, which may have led to alteration of original Ti-magnetite to Ti-hematite.

In order to identify the carriers of the ipAMS fabric in the Sosa dyke samples, we employed AARM, AIRM and opAMS to distinguish eventual magnetic subfabrics. Representative sub-specimens from each sample were selected for comparison between different magnetic fabrics. AARM and AIRM are controlled by magnetic remanence and are used to measure the fabric of ferrimagnetic minerals in isolation from other rock forming minerals [70,115-117]. Low-field AIRM can single-out the contribution of low-coercivity grains such as multi-domain magnetite to the AMS fabric [118-120], whereas AARM also can be used to identify the fabric of both MD ferrimagnetic particles and higher coercivity single-domain ferrimagnetic particles [70,115-117]. Modelling by Hrouda et al. [57] show that ipAMS, opAMS and remanence magnetization may be carried by different types of magnetic particles. In a sample where ipAMS, opAMS and Anisotropy of Magnetic Remanence (AMR) are coaxial, the AMS fabric is likely carried by MD magnetite. However, when the measured magnetic fabrics are non-coaxial, magnetic subfabrics carried by different grain sizes and minerals may be present in the sample. Whereas ipAMS may be carried by several different particle fractions, opAMS in particular may be carried by viscous multiparticle systems with single-domain and superparamagnetic particles. AARM are not carried by viscous multiparticle systems but can be carried by stable single domain particles. Based on the information presented above one can identify the magnetic carriers in the samples of our traverses. 

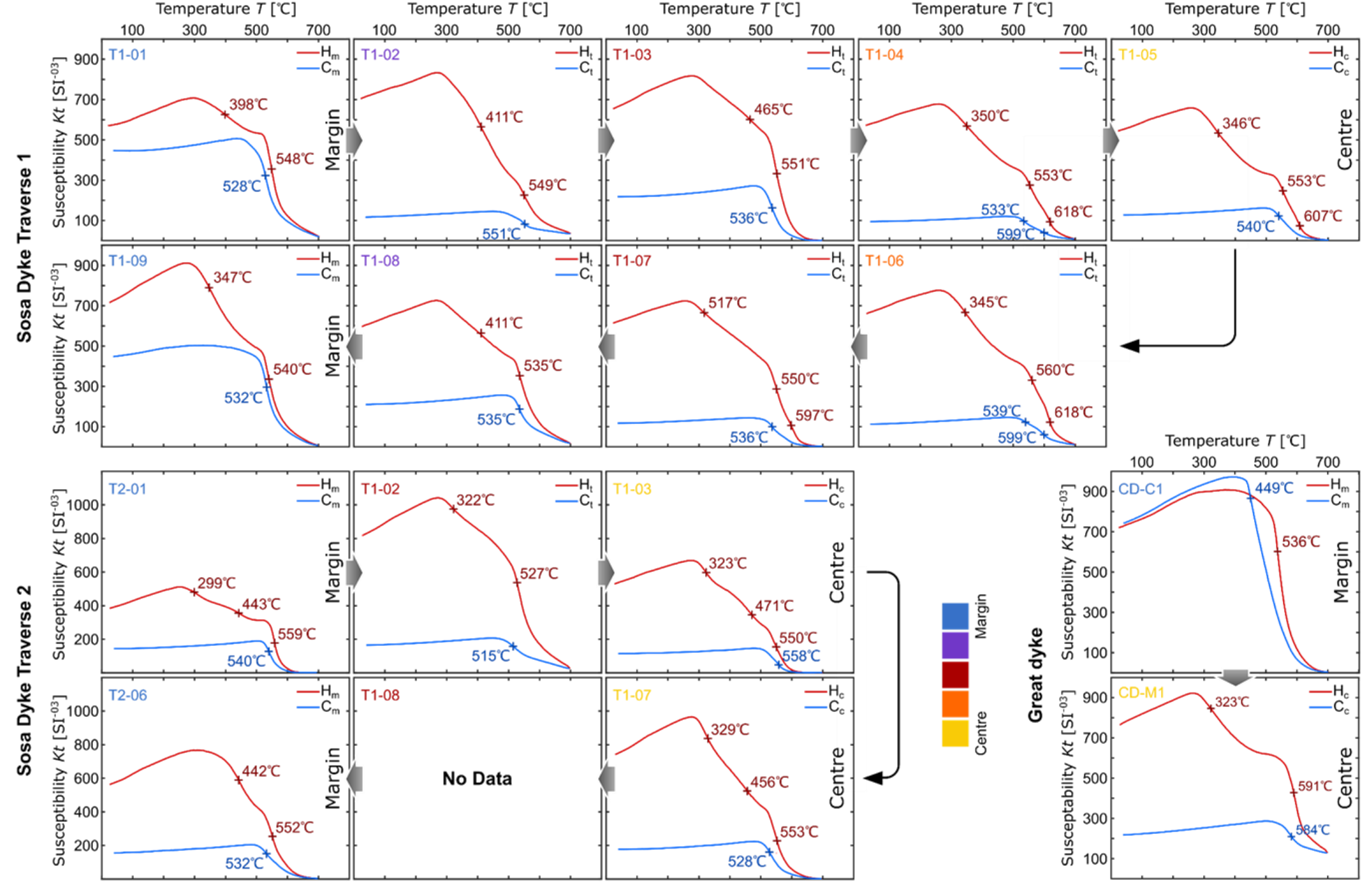

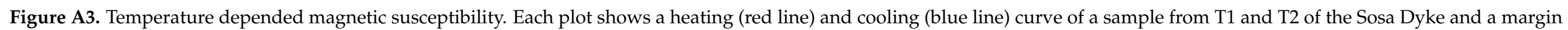
and centre sample of the Great Dyke. Temperature values indicate local extrema of the first derivative. 

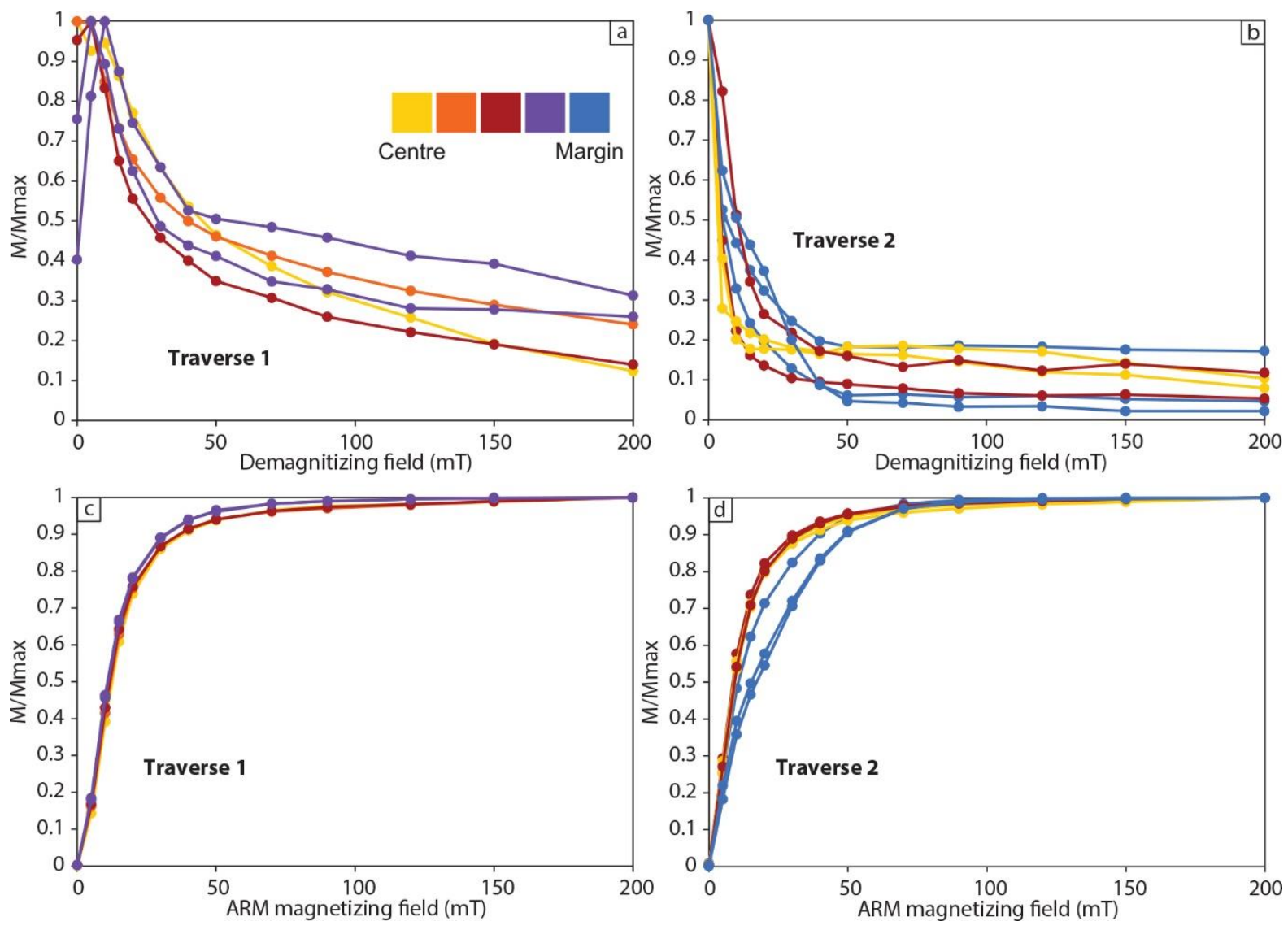

Figure A4. NRM (a) and (b) and ARM (c) and (d) magnetization plots. The samples stepwise demagnetised along 3-axes $(\mathrm{x}+, \mathrm{y}+, \mathrm{z}+)$ to a maximum AC field of $200 \mathrm{mT}$. During ARM magnetization, the selected specimens were imparted with a stepwise increasing AC field and constant DC field of $500 \mu \mathrm{T}$ along the specimen $\mathrm{z}+$ axis to maximum AC field of $200 \mathrm{mT}$.

In traverse T1, samples T1-05 and 06, the ipAMS $\mathrm{k}_{1}$, AARM and AIRM $\mathrm{R}_{1}$ axes plot close to each other and the ipAMS $k_{2}$ and $k_{3}, A A R M$ and AIRM $R_{2}$ and $R_{3}$ axes plot on the same girdle (Figure A5). The opAMS $\mathrm{k}_{1}$ axes are offset about 30 degrees from the ipAMS $\mathrm{k}_{1}$ axes. The coaxial ipAMS and AMR fabrics suggest that MD magnetite is the main magnetic carrier in these two samples. In sample T1-07, the ipAMS and AARM principal axes plot close to each other, and conversely the AIRM and opAMS plot close to each other (Figure A5). The fabric suggests that the AMS is dominated by MD magnetite and SD magnetite, occurring in inclusions and breakdown rims in amphibole. The opAMS and AIRM likely show the fabric of viscous multiparticle and MD grains in the groundmass of the sample. In sample T1-08 the ipAMS $k_{1}$ and $k_{2}, A A R M$ and AIRM $R_{1}$ and $R_{2}$ axes plot on the same girdle and the ipAMS $k_{3}, A A R M$ and AIRM $R_{3}$ axes plot close to each other (Figure A5). The opAMS principal axes are non-coaxial relative to the other magnetic fabrics in the sample. The general coaxial AMS and AMR show that the samples ipAMS is dominated by multidomain magnetite and likely also the amphibole shape fabric enhanced by SD magnetite in breakdown rims and in inclusions (cf. [121-123]). The opAMS fabrics likely represent the groundmass fabric as evidenced by the wide girdle distribution of opAMS tensors. 

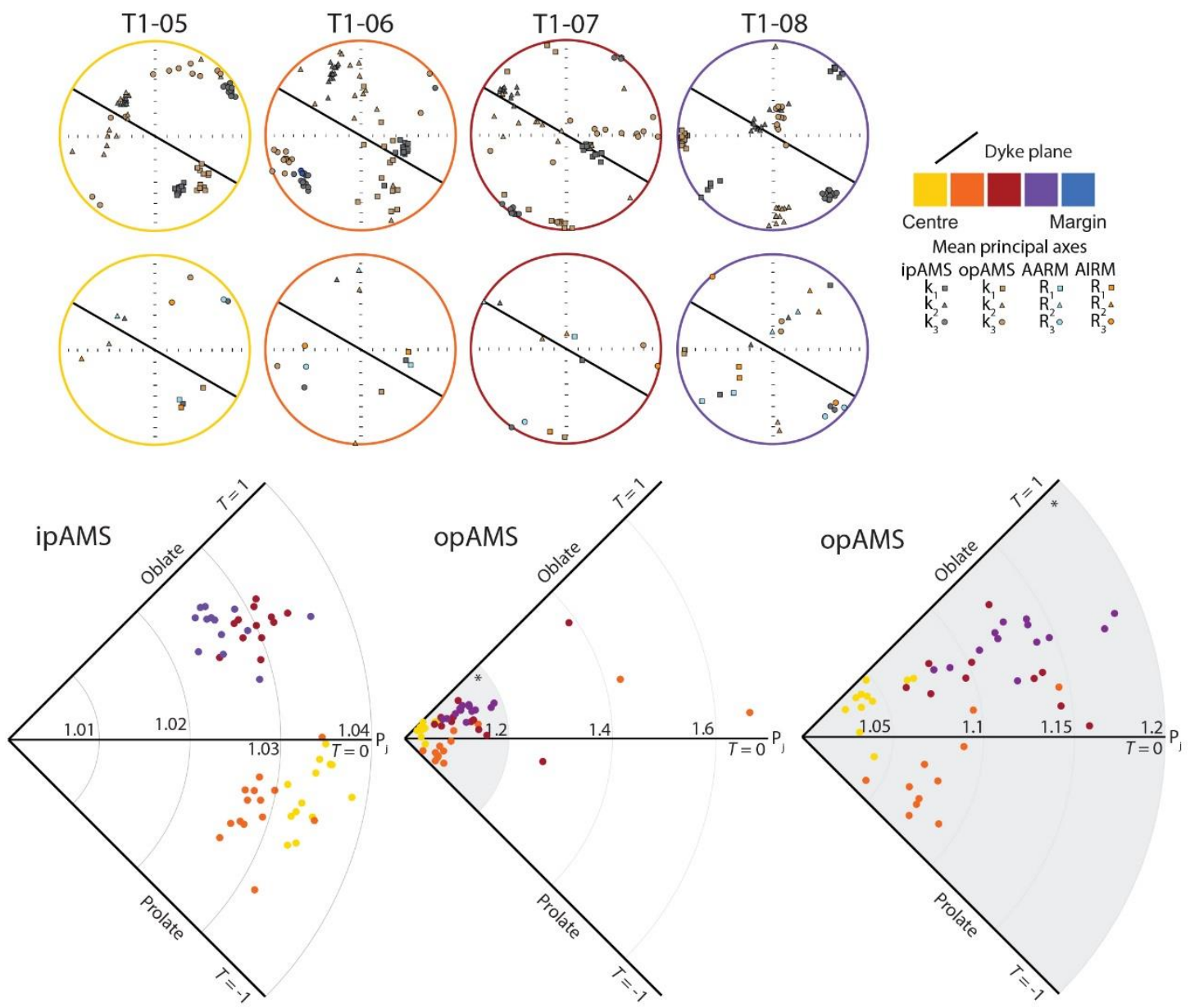

Figure A5. Comparison between different magnetic fabrics analysed on samples in traverse T1 of the Sosa dyke.

In traverse T2, the ip and opAMS, AIRM and AARM principal axes are coaxial in samples T2-02 and T2-06 and plot close to each other in T2-03 and T2-04 (Figure A6). This indicates that MD magnetite dominate the magnetic fabrics in these samples. In sample T2-01, opAMS $k_{1}$ and $k_{2}$, AARM and AIRM $R_{1}$ and $R_{2}$ axes plot on the same girdle and the $k_{3}$ and $R_{3}$ occur in a cluster (Figure A6). The ipAMS $k_{1}$ plots on the opAMS $k_{1}$ and $k_{2}$ girdle, whereas ipAMS $k_{2}$ plots close to opAMS $k_{3}$. The ipAMS may therefore reflect the amphibole fabric in the rock enhanced by magnetite inclusions, which produce a strong lineation, while the opAMS and AARM and AIRM reflect the distribution of MD magnetite in the groundmass of the sample. In sample T2-05, ipAMS principal axes are coaxial with AARM principal axes. Both AIRM and opAMS principal axes are oriented oblique to ipAMS and AARM principal axes (Figure A6). The general coaxial AMS and AARM show that the samples ipAMS is dominated by multidomain magnetite and likely also the amphibole shape fabric enhanced by SD magnetite in breakdown rims and in inclusions. The opAMS and AIRM fabric in these samples may be controlled the fabric of smaller magnetite crystals in the groundmass of the sample. To summarise, the magnetic fabrics in the Sosa dyke traverse are complex. However, the general coaxial AARM and ipAMS fabric show that it is not magnetically inverse and likely represents the MD and silicate fabric in the samples. All magnetic data are given in the Supplementary Material "Magnetic data.xlsx" (separate document). 

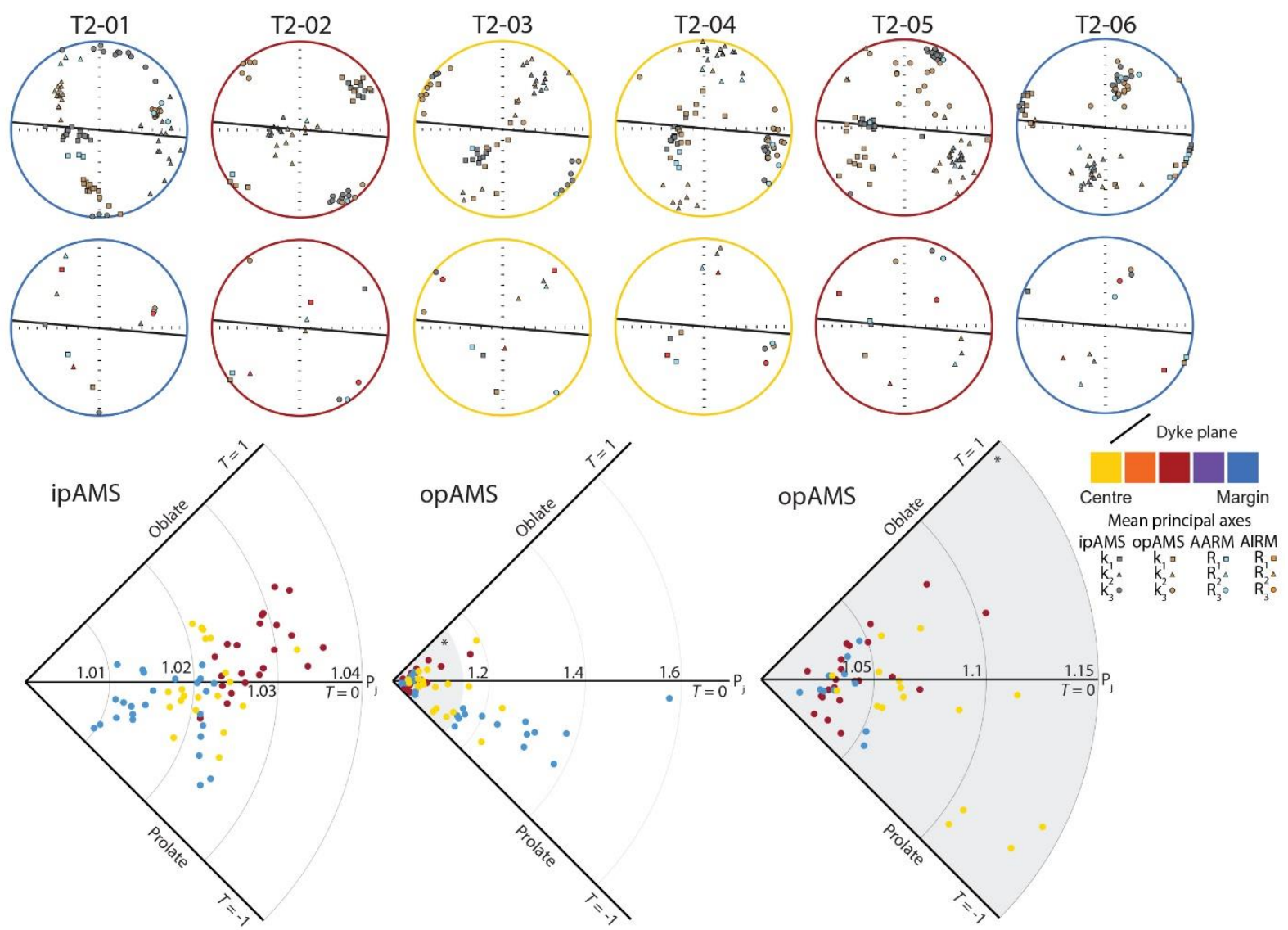

Figure A6. Comparison between different magnetic fabrics analysed on samples in traverse T2 of the Sosa dyke.

\section{Appendix C. Data Figure 9}

Table A4. Sosa and Great Dyke data for Figure 9.

\begin{tabular}{|c|c|c|c|c|c|}
\hline Segment & $r_{\text {tip }}(\mathrm{m})$ & $w(m)$ & $t(m)$ & $\mathrm{r}_{\mathrm{tip}} / \mathrm{w}$ & $t / w$ \\
\hline \multicolumn{6}{|c|}{ Sosa Dyke } \\
\hline $\mathrm{SI}_{3}$ & 25.34 & 560 & 51 & 0.02 & 0.09 \\
\hline SII & 17.47 & 210 & 61 & 0.04 & 0.29 \\
\hline SIII & 64.17 & 203 & 74 & 0.16 & 0.36 \\
\hline \multicolumn{6}{|c|}{ Great Dyke } \\
\hline Segment1 & 3.10 & 78 & 27 & 0.04 & 0.35 \\
\hline Segment1 & 7.00 & 78 & 27 & 0.09 & 0.35 \\
\hline Segment2 & 9.09 & 45 & 23 & 0.20 & 0.51 \\
\hline Segment2 & 8.67 & 45 & 23 & 0.19 & 0.51 \\
\hline Segment3 & 7.75 & 95 & 25 & 0.08 & 0.26 \\
\hline Segment3 & 11.42 & 95 & 25 & 0.12 & 0.26 \\
\hline Segment 4 & 10.42 & 145 & 29 & 0.07 & 0.20 \\
\hline Segment4 & 8.83 & 145 & 29 & 0.06 & 0.20 \\
\hline Segment5 & 12.51 & 158 & 32 & 0.08 & 0.20 \\
\hline Segment5 & 13.09 & 158 & 32 & 0.08 & 0.20 \\
\hline Segment6 & 14.08 & 93 & 40 & 0.15 & 0.43 \\
\hline Segment6 & 14.42 & 93 & 40 & 0.16 & 0.43 \\
\hline Segment7 & 10.25 & 1110 & 36 & 0.01 & 0.03 \\
\hline Segment7 & 10.68 & 1110 & 36 & 0.01 & 0.03 \\
\hline Segment8 & 5.58 & 220 & 21 & 0.03 & 0.10 \\
\hline Segment8 & 1.61 & 220 & 21 & 0.01 & 0.10 \\
\hline
\end{tabular}




\section{References}

1. Kavanagh, J.L. Chapter 3-Mechanisms of Magma Transport in the Upper Crust-Dyking. In Volcanic and Igneous Plumbing Systems Understanding Magma Transport, Storage, and Evolution in the Earth's Crust; Burchardt, S., Ed.; Elsevier: Amsterdam, The Netherlands, 2018; pp. 55-88. ISBN 978-0-12-809749-6.

2. Cruden, A.R.; McCaffrey, K.J.W.; Bunger, A.P. Geometric Scaling of Tabular Igneous Intrusions: Implications for Emplacement and Growth. In Physical Geology of Shallow Magmatic Systems: Dykes, Sills and Laccoliths; Breitkreuz, C., Rocchi, S., Eds.; Springer International Publishing: Cham, Switzerland, 2018; pp. 11-38. ISBN 978-3-319-14084-1.

3. Galland, O.; Bertelsen, H.S.; Eide, C.H.; Guldstrand, F.; Haug, Ø.T.; Leanza, H.A.; Mair, K.; Palma, O.; Planke, S.; Rabbel, O.; et al. Storage and Transport of Magma in the Layered Crust-Formation of Sills and Related Flat-Lying Intrusions. In Volcanic and Igneous Plumbing Systems; Burchardt, S., Ed.; Elsevier: Amsterdam, The Netherlands, 2018; pp. 111-136. ISBN 9780128097496.

4. Sigmundsson, F. New insights into magma plumbing along rift systems from detailed observations of eruptive behavior at Axial volcano. Geophys. Res. Lett. 2016, 43, 12.423-12.427. [CrossRef]

5. Chen, K.; Smith, J.D.; Avouac, J.-P.; Liu, Z.; Song, Y.T.; Gualandi, A. Triggering of the Mw 7.2 Hawaii Earthquake of 4 May 2018 by a Dike Intrusion. Geophys. Res. Lett. 2019, 46, 2503-2510. [CrossRef]

6. Wicks, C.; de la Llera, J.C.; Lara, L.E.; Lowenstern, J. The role of dyking and fault control in the rapid onset of eruption at Chaitén volcano, Chile. Nature 2011, 478, 374-377. [CrossRef] [PubMed]

7. Fahrig, W.F.; Halls, H.C. Mafic Dyke Swarms; Geological Association of Canada: Toronto, ON, Canada, 1987 ; p. 503.

8. Kjøll, H.J.; Galland, O.; Labrousse, L.; Andersen, T.B. Emplacement mechanisms of a dyke swarm across the brittle-ductile transition and the geodynamic implications for magma-rich margins. Earth Planet. Sci. Lett. 2019, 518, 223-235. [CrossRef]

9. Melnik, O.; Barmin, A.A.; Sparks, R.S.J. Dynamics of magma flow inside volcanic conduits with bubble overpressure buildup and gas loss through permeable magma. J. Volcanol. Geotherm. Res. 2005, 143, 53-68. [CrossRef]

10. Michaut, C.; Ricard, Y.; Bercovici, D.; Sparks, R.S.J. Eruption cyclicity at silicic volcanoes potentially caused by magmatic gas waves. Nat. Geosci. 2013, 6, 856-860. [CrossRef]

11. Emerman, S.H.; Marrett, R. Why dikes? Geology 1990, 18, 231-233. [CrossRef]

12. Burchardt, S. Volcanic and Igneous Plumbing Systems: Understanding Magma Transport, Storage, and Evolution in the Earth's Crust; Elsevier: Amsterdam, The Netherlands, 2018; ISBN 9780128097496.

13. Rocchi, S.; Breitkreuz, C. Physical Geology of Shallow-Level Magmatic Systems-An Introduction. In Physical Geology of Shallow Magmatic Systems: Dykes, Sills and Laccoliths; Breitkreuz, C., Rocchi, S., Eds.; Springer International Publishing: Cham, Germany, 2017; pp. 1-10. ISBN 978-3-319-14084-1.

14. Jay, J.; Costa, F.; Pritchard, M.; Lara, L.; Singer, B.; Herrin, J. Locating magma reservoirs using InSAR and petrology before and during the 2011-2012 Cordón Caulle silicic eruption. Earth Planet. Sci. Lett. 2014, 395, 254-266. [CrossRef]

15. Heiken, G.; Wohletz, K.; Eichelberger, J. Fracture fillings and intrusive pyroclasts, Inyo Domes, California. J. Geophys. Res. Solid Earth 1988, 93, 4335-4350. [CrossRef]

16. Eichelberger, J.C.; Carrigan, C.R.; Westrich, H.R.; Price, R.H. Non-explosive silicic volcanism. Nature 1986, 323, 598-602. [CrossRef]

17. Watkins, H.; Healy, D.; Bond, C.E.; Butler, R.W.H. Implications of heterogeneous fracture distribution on reservoir quality; an analogue from the Torridon Group sandstone, Moine Thrust Belt, NW Scotland. J. Struct. Geol. 2018, 108, 180-197. [CrossRef]

18. Healy, D.; Rizzo, R.; Duffy, M.; Farrell, N.; Hole, M.; Muirhead, D. Field evidence for the lateral emplacement of igneous dykes: Implications for 3D mechanical models and the plumbing beneath fissure eruptions. Volcanica 2018, 1, 85-105. [CrossRef]

19. Rubin, A.M. Propagation of Magma-Filled Cracks. Annu. Rev. Earth Planet. Sci. 1995, 23, 287-336. [CrossRef]

20. Rivalta, E.; Taisne, B.; Bunger, A.P.; Katz, R.F. A review of mechanical models of dike propagation: Schools of thought, results and future directions. Tectonophysics 2015, 638, 1-42. [CrossRef]

21. Poppe, S.; Galland, O.; de Winter, N.J.; Goderis, S.; Claeys, P.; Debaille, V.; Boulvais, P.; Kervyn, M. Structural and Geochemical Interactions Between Magma and Sedimentary Host Rock: The Hovedøya Case, Oslo Rift, Norway. Geochem. Geophys. Geosystems 2020, 21, e2019GC008685. [CrossRef]

22. Rubin, A.M. On the thermal viability of dikes leaving magma chambers. Geophys. Res. Lett. 1993, 20, 257-260. [CrossRef]

23. Burchardt, S.; Tanner, D.C.; Troll, V.R.; Krumbholz, M.; Gustafsson, L.E. Three-dimensional geometry of concentric intrusive sheet swarms in the Geitafell and the Dyrfjöll volcanoes, eastern Iceland. Geochem. Geophys. Geosystems 2011, 12, Q0AB09. [CrossRef]

24. Daniels, K.A.; Kavanagh, J.L.; Menand, T.; Stephen, J.S.R. The shapes of dikes: Evidence for the influence of cooling and inelastic deformation. GSA Bull. 2012, 124, 1102-1112. [CrossRef]

25. Pollard, D.D.; Muller, O.H.; Dockstader, D.R. The Form and Growth of Fingered Sheet Intrusions. Geol. Soc. Am. Bull. 1975, 86, 351-363. [CrossRef]

26. Spacapan, J.B.; Galland, O.; Leanza, H.A.; Planke, S. Igneous sill and finger emplacement mechanism in shale-dominated formations: A field study at Cuesta del Chihuido, Neuquén Basin, Argentina. J. Geol. Soc. Lond. 2017, 174, 422-433. [CrossRef]

27. Galland, O.; Spacapan, J.B.; Rabbel, O.; Mair, K.; Soto, F.G.; Eiken, T.; Schiuma, M.; Leanza, H.A.; Spacapan, J.B.; Soto, F.G.; et al. Structure, emplacement mechanism and magma-flow significance of igneous fingers - Implications for sill emplacement in sedimentary basins. J. Struct. Geol. 2019, 124, 120-135. [CrossRef]

28. Stephens, T.L.; Walker, R.J.; Healy, D.; Bubeck, A. Segment tip geometry of sheet intrusions, II: Field observations of tip geometries and a model for evolving emplacement mechanisms. EarthARXiv 2020. Available online: https:/ / eartharxiv.org/repository/ view /1794/ (accessed on 10 October 2021). [CrossRef] 
29. Schofield, N.; Stevenson, C.; Reston, T. Magma fingers and host rock fluidization in the emplacement of sills. Geology 2010, 38, 63-66. [CrossRef]

30. Schmiedel, T.; Galland, O.; Breitkreuz, C. Dynamics of Sill and Laccolith Emplacement in the Brittle Crust: Role of Host Rock Strength and Deformation Mode. J. Geophys. Res. Solid Earth 2017, 122, 8860-8871. [CrossRef]

31. Schofield, N.; Brown, D.J.; Magee, C.; Stevenson, C.T. Sill morphology and comparison of brittle and non-brittle emplacement mechanisms. J. Geol. Soc. Lond. 2012, 169, 127-141. [CrossRef]

32. Bertelsen, H.; Rogers, B.; Galland, O.; Dumazer, G.; Benanni, A. Laboratory modeling of coeval brittle and ductile deformation during magma emplacement into viscoelastic rocks. Front. Earth Sci. 2018, 6, 1-16. [CrossRef]

33. Knight, M.D.; Walker, G.P.L. Magma flow directions in dikes of the Koolau complex, Oahu, determined from magnetic fabric studies (Hawaii). J. Geophys. Res. Solid Earth 1988, 93, 4301-4319. [CrossRef]

34. Tauxe, L.; Gee, J.S.; Staudigel, H. Flow directions in dikes from anisotropy of magnetic susceptibility data: The bootstrap way. J. Geophys. Res. Solid Earth 1998, 103, 17775-17790. [CrossRef]

35. Poland, M.P.; Fink, J.H.; Tauxe, L. Patterns of magma flow in segmented silicic dikes at Summer Coon volcano, Colorado: AMS and thin section analysis. Earth Planet. Sci. Lett. 2004, 219, 155-169. [CrossRef]

36. Abdelmalak, M.M.; Mourgues, R.; Galland, O.; Bureau, D. Fracture mode analysis and related surface deformation during dyke intrusion: Results from 2D experimental modelling. Earth Planet. Sci. Lett. 2012, 359-360, 93-105. [CrossRef]

37. Guldstrand, F.; Burchardt, S.; Hallot, E.; Galland, O. Dynamics of Surface Deformation Induced by Dikes and Cone Sheets in a Cohesive Coulomb Brittle Crust. J. Geophys. Res. Solid Earth 2017, 122, 8511-8524. [CrossRef]

38. Castro, J.M.; Dingwell, D.B. Rapid ascent of rhyolitic magma at Chaitén volcano, Chile. Nature 2009, 461, 780-783. [CrossRef] [PubMed]

39. Castro, J.M.; Schipper, C.I.; Mueller, S.P.; Militzer, A.S.; Amigo, A.; Parejas, C.S.; Jacob, D. Storage and eruption of near-liquidus rhyolite magma at Cordón Caulle, Chile. Bull. Volcanol. 2013, 75, 702. [CrossRef]

40. Bertelsen, H.S.; Guldstrand, F.; Sigmundsson, F.; Pedersen, R.; Mair, K.; Galland, O. Beyond elasticity: Are Coulomb properties of the Earth's crust important for volcano geodesy? J. Volcanol. Geotherm. Res. 2021, 410, 107153. [CrossRef]

41. Burchardt, S. Chapter 12-Synthesis on the State-of-the-Art and Future Directions in the Research on Volcanic and Igneous Plumbing Systems. In Volcanic and Igneous Plumbing Systems Understanding Magma Transport, Storage, and Evolution in the Earth's Crust; Burchardt, S., Ed.; Elsevier: Amsterdam, The Netherlands, 2018; pp. 323-333. ISBN 978-0-12-809749-6.

42. Magee, C.; Stevenson, C.T.E.; Ebmeier, S.K.; Keir, D.; Hammond, J.O.S.; Gottsmann, J.H.; Whaler, K.A.; Schofield, N.; Jackson, C.A.L.; Petronis, M.S.; et al. Magma plumbing systems: A geophysical perspective. J. Petrol. 2018, 59, 1217-1251. [CrossRef]

43. Llambías, E.J.; Bertotto, G.W.; Risso, C.; Hernando, I. El volcanismo cuaternario en el retroarco de Payenia: Una revisión. Rev. la Asoc. Geol. Argentina 2010, 67, 278-300.

44. Folguera, A.; Ramos, V.A. Repeated eastward shifts of arc magmatism in the Southern Andes: A revision to the long-term pattern of Andean uplift and magmatism. J. South Am. Earth Sci. 2011, 32, 531-546. [CrossRef]

45. Kay, S.M.; Mancilla, O.; Copeland, P. Evolution of the late Miocene Chachahuén volcanic complex at $37^{\circ} \mathrm{S}$ over a transient shallow subduction zone under the Neuquén Andes. Geol. Soc. Am. Spec. Pap. 2006, 407, 215-246. [CrossRef]

46. Holmberg, E. Descripción Geológica de la Hoja 32 d, Chachahuén. Provincia del Neuquén - Provincia de Mendoza. Escala 1:200.000. Carta Geológico-Económica de la República Argentina. Boletines del SEGEMAR 1962, 91, 70.

47. González Díaz, E.F. Descripción Geológica de la Hoja 31 d, La Matancilla. Provincia de Mendoza. Escala 1:200.000. Carta Geológico-Económica de la República Argentina. Boletines del SEGEMAR 1979, 173, 97.

48. Perez, M.A.; Condat, P. Geología de la Sierra de Chachahuén, Á rea CNQ-23; Puelen: Buenos Aires, Argentina, 1996.

49. Burchardt, S.; Mattsson, T.; Palma, J.O.; Galland, O.; Almqvist, B.; Mair, K.; Jerram, D.A.; Hammer, Ø.; Sun, Y. Progressive Growth of the Cerro Bayo Cryptodome, Chachahuén Volcano, Argentina-Implications for Viscous Magma Emplacement. J. Geophys. Res. Solid Earth 2019, 124, 7934-7961. [CrossRef]

50. Sagripanti, L.; Aguirre-Urreta, B.; Folguera, A.; Ramos, V.A. The Neocomian of Chachahuén (Mendoza, Argentina): Evidence of a broken foreland associated with the Payenia flat-slab. Geol. Soc. Lond. Spec. Publ. 2015, 399, 203-219. [CrossRef]

51. Guldstrand, F.; Schmiedel, T. 2021. Available online: https://zenodo.org/record/4784165/export/hx\#.YWP33xpByUk (accessed on 4 October 2021).

52. Jelínek, V. Statistical processing of anisotropy of magnetic susceptibility measured on groups of specimens. Stud. Geophys. Geod. 1978, 22, 50-62. [CrossRef]

53. Khan, M.A. The anisotropy of magnetic susceptibility of some igneous and metamorphic rocks. J. Geophys. Res. 1962, 67, 2873-2885. [CrossRef]

54. Jelinek, V. Characterization of the magnetic fabric of rocks. Tectonophysics 1981, 79, T34-T67. [CrossRef]

55. Chadima, M.; Hrouda, F.; Jelínek, V. Anisoft5; AGICO: Brno, Czech Republic, 2020.

56. Hrouda, F.; Chadima, M.; Ježek, J.; Pokorný, J. Anisotropy of out-of-phase magnetic susceptibility of rocks as a tool for direct determination of magnetic subfabrics of some minerals: An introductory study. Geophys. J. Int. 2017, 208, 385-402. [CrossRef]

57. Hrouda, F.; Ježek, J.; Chadima, M. Anisotropy of out-of-phase magnetic susceptibility as a potential tool for distinguishing geologically and physically controlled inverse magnetic fabrics in volcanic dykes. Phys. Earth Planet. Inter. 2020, $307,106551$. [CrossRef]

58. Hext, G.R. The estimation of second-order tensors, with related tests and designs. Biometrika 1963, 50, 353-373. [CrossRef] 
59. Jelínek, V. The Statistical Theory of Measuring Anisotropy of Magnetic Susceptibility of Rocks and Its Application; Geofyzika: Brno, Czech Republic, 1977.

60. Jackson, L.L.; Brown, F.W.; Neil, S.T. Major and minor elements requiring individual determination, classical whole rock analysis, and rapid rock analysis. US Geol. Surv. Bull. 1987, 1770, G1-G23.

61. von Aulock, F.W.; Kennedy, B.M.; Schipper, C.I.; Castro, J.M.E.; Martin, D.; Oze, C.; Watkins, J.M.; Wallace, P.J.; Puskar, L.; Bégué, F.; et al. Advances in Fourier transform infrared spectroscopy of natural glasses: From sample preparation to data analysis. Lithos 2014, 206-207, 52-64. [CrossRef]

62. McIntosh, I.M.; Llewellin, E.W.; Humphreys, M.C.S.; Nichols, A.R.L.; Burgisser, A.; Schipper, C.I.; Larsen, J.F. Distribution of dissolved water in magmatic glass records growth and resorption of bubbles. Earth Planet. Sci. Lett. 2014, 401, 1-11. [CrossRef]

63. McIntosh, I.M.; Nichols, A.R.L.; Tani, K.; Llewellin, E.W. Accounting for the species-dependence of the $3500 \mathrm{~cm}-1 \mathrm{H} 2 \mathrm{Ot}$ infrared molar absorptivity coefficient: Implications for hydrated volcanic glasses. Am. Mineral. 2017, 102, 1677-1689. [CrossRef]

64. Bottinga, Y.; Weill, D.F. The viscosity of magmatic silicate liquids; a model calculation. Am. J. Sci. 1972, 272, 438-475. [CrossRef]

65. Lamé, G. Examen des Différentes Méthodes Employées Pour Résoudre les Problémes de Géométrie; M V Courcier: Paris, France, 1818.

66. Walker, R.; Stephens, T.L.; Greenfield, C.; Gill, S.; Healy, D.; Poppe, S. Segment tip geometry of sheet intrusions, I: Theory and numerical models for the role of tip shape in controlling propagation pathways. EarthArXiv 2021. Available online: https: / / eartharxiv.org/ (accessed on 10 October 2021). [CrossRef]

67. Hargraves, R.B.; Johnson, D.; Chan, C.Y. Distribution anisotropy: The cause of AMS in igneous rocks? Geophys. Res. Lett. 1991, 18, 2193-2196. [CrossRef]

68. Stephenson, A. Distribution anisotropy: Two simple models for magnetic lineation and foliation. Phys. Earth Planet. Inter. 1994, 82, 49-53. [CrossRef]

69. Cañón-Tapia, E. Factors affecting the relative importance of shape and distribution anisotropy in rocks: Theory and experiments. Tectonophysics 2001, 340, 117-131. [CrossRef]

70. Borradaile, G.J.G.J.; Jackson, M. Structural geology, petrofabrics and magnetic fabrics (AMS, AARM, AIRM). J. Struct. Geol. 2010, 32, 1519-1551. [CrossRef]

71. Mattsson, T.; Petri, B.; Almqvist, B.S.G.; McCarthy, W.; Burchardt, S.; Palma, J.O.; Hammer, Ø.; Galland, O. Decrypting magnetic fabrics (AMS, AARM, AIRM) through the analysis of mineral shape fabrics and distribution anisotropy. J. Geophys. Res. Solid Earth 2021, 126, e2021JB021895. [CrossRef]

72. Browne, B.L.; Gardner, J.E. The influence of magma ascent path on the texture, mineralogy, and formation of hornblende reaction rims. Earth Planet. Sci. Lett. 2006, 246, 161-176. [CrossRef]

73. Huppert, H.E.; Sparks, R.S.J. Chilled margins in igneous rocks. Earth Planet. Sci. Lett. 1989, 92, 397-405. [CrossRef]

74. Schmiedel, T.; Kjoberg, S.; Planke, S.; Magee, C.; Galland, O.; Schofield, N.; Jackson, C.A.-L.; Jerram, D.A. Mechanisms of overburden deformation associated with the emplacement of the Tulipan sill, mid-Norwegian margin. Interpretation 2017, 5, SK23-SK38. [CrossRef]

75. Köpping, J.; Magee, C.; Cruden, A.R.; Jackson, C.A.-L.; Norcliffe, J. The building blocks of igneous sheet intrusions: Insights from 3D seismic reflection data. EarthArXiv 2021. [CrossRef]

76. Eide, C.H.; Schofield, N.; Lecomte, I.; Buckley, S.J.; Howell, J.A. Seismic interpretation of sill complexes in sedimentary basins: Implications for the sub-sill imaging problem. J. Geol. Soc. Lond. 2018, 175, 193-209. [CrossRef]

77. Wiebe, R.A.; Ulrich, R. Origin of composite dikes in the Gouldsboro granite, coastal Maine. Lithos 1997, 40, 157-178. [CrossRef]

78. Eriksson, P.I.; Riishuus, M.S.; Sigmundsson, F.; Elming, S.-Å.Å. Magma flow directions inferred from field evidence and magnetic fabric studies of the Streitishvarf composite dike in east Iceland. J. Volcanol. Geotherm. Res. 2011, 206, 30-45. [CrossRef]

79. Carrigan, C.R.; Eichelberger, J.C. Zoning of magmas by viscosity in volcanic conduits. Nature 1990, 343, 248-251. [CrossRef]

80. Geoffroy, L.; Callot, J.P.; Aubourg, C.; Moreira, M. Magnetic and plagioclase linear fabric discrepancy in dykes: A new way to define the flow vector using magnetic foliation. Terra Nov. 2002, 14, 183-190. [CrossRef]

81. Chadima, M.; Cajz, V.; Týcová, P. On the interpretation of normal and inverse magnetic fabric in dikes: Examples from the Eger Graben, NW Bohemian Massif. Tectonophysics 2009, 466, 47-63. [CrossRef]

82. Andersson, M.; Almqvist, B.S.G.; Burchardt, S.; Troll, V.R.; Malehmir, A.; Snowball, I.; Kübler, L. Magma transport in sheet intrusions of the Alnö carbonatite complex, central Sweden. Sci. Rep. 2016, 6, 27635. [CrossRef]

83. Magee, C.; Muirhead, J.D.; Karvelas, A.; Holford, S.P.; Jackson, C.A.L.; Bastow, I.D.; Schofield, N.; Stevenson, C.T.E.; McLean, C.; McCarthy, W. Lateral magma flow in mafic sill complexes. Geosphere 2016, 12, 809-841. [CrossRef]

84. Hutton, D.H.W. Insights into magmatism in volcanic margins: Bridge structures and a new mechanism of basic sill emplacementTheron Mountains, Antarctica. Pet. Geosci. 2009, 15, 269-278. [CrossRef]

85. Magee, C.; Muirhead, J.; Schofield, N.; Walker, R.J.; Galland, O.; Holford, S.; Spacapan, J.; Jackson, C.A.-L.; McCarthy, W. Structural signatures of igneous sheet intrusion propagation. J. Struct. Geol. 2019, 125, 148-154. [CrossRef]

86. Delaney, P.T.; Pollard, D.D. United States Government Printing Office. Deformation of Host Rocks and Flow of Magma during Growth of Minette Dikes and Breccia-Bearing Intrusions near Ship Rock, New Mexico; United States Government Printing Office: Washington, DC, USA, 1981.

87. Kjoberg, S.; Schmiedel, T.; Planke, S.; Svensen, H.H.; Millett, J.M.; Jerram, D.A.; Galland, O.; Lecomte, I.; Schofield, N.; Haug, Ø.T.; et al. 3D structure and formation of hydrothermal vent complexes at the Paleocene-Eocene transition, the Møre Basin, mid-Norwegian margin. Interpretation 2017, 5, SK65-SK81. [CrossRef] 
88. Arachchige, U.N.; Cruden, A.R.; Weinberg, R. Laponite gels - visco-elasto-plastic analogues for geological laboratory modelling. Tectonophysics 2021, 805, 228773. [CrossRef]

89. Kavanagh, J.L.; Engwell, S.L.; Martin, S.A. A review of laboratory and numerical modelling in volcanology. Solid Earth 2018, 9 , 531-571. [CrossRef]

90. Townsend, M.R.; Pollard, D.D.; Smith, R.P. Mechanical models for dikes: A third school of thought. Tectonophysics 2017, 703, 98-118. [CrossRef]

91. Vachon, R.; Bazargan, M.; Hieronymus, C.F.; Ronchin, E.; Almqvist, B. Crystal rotations and alignment in spatially varying magma flows: 2-D examples of common subvolcanic flow geometries. Geophys. J. Int. 2021, 226, 709-727. [CrossRef]

92. Poland, M.P.; Moats, W.P.; Fink, J.H. A model for radial dike emplacement in composite cones based on observations from Summer Coon volcano, Colorado, USA. Bull. Volcanol. 2008, 70, 861-875. [CrossRef]

93. Takeuchi, S. Preeruptive magma viscosity: An important measure of magma eruptibility. J. Geophys. Res. Solid Earth 2011, 116, 19. [CrossRef]

94. Richet, P.; Lejeune, A.-M.; Holtz, F.; Roux, J. Water and the viscosity of andesite melts. Chem. Geol. 1996, 128, 185-197. [CrossRef]

95. Heap, M.J.; Violay, M.E.S. The mechanical behaviour and failure modes of volcanic rocks: A review. Bull. Volcanol. 2021, 83, 47 . [CrossRef]

96. Eide, C.H.; Schofield, N.; Jerram, D.A.; Howell, J.A. Basin-scale architecture of deeply emplaced sill complexes: Jameson Land, East Greenland. J. Geol. Soc. Lond. 2016, 174, 23-40. [CrossRef]

97. Haug, Ø.T.; Galland, O.; Souloumiac, P.; Souche, A.; Guldstrand, F.; Schmiedel, T. Inelastic damage as a mechanical precursor for the emplacement of saucer-shaped intrusions. Geology 2017, 45, 1099-1102. [CrossRef]

98. Schmiedel, T.; Galland, O.; Haug, Ø.T.; Dumazer, G.; Breitkreuz, C. Coulomb failure of Earth's brittle crust controls growth, emplacement and shapes of igneous sills, saucer-shaped sills and laccoliths. Earth Planet. Sci. Lett. 2019, 510, 161-172. [CrossRef]

99. Galland, O.; Burchardt, S.; Hallot, E.; Mourgues, R.; Bulois, C. Dynamics of dikes versus cone sheets in volcanic systems. J. Geophys. Res. Solid Earth 2014, 119, 6178-6192. [CrossRef]

100. Galland, O.; Schmiedel, T.; Bertelsen, H.; Guldstrand, F.; Haug, Ø.T.; Souche, A. Geomechanical Modeling of Fracturing and Damage induced by Igneous Intrusions: Implications for Fluid Flow in Volcanic Basins. In Proceedings of the X Congreso de Exploración y Desarrollo de Hidrocarburos, Mendoza, Argentina, 5-9 November 2018; Instituto Argentino del Petróleo y el Gas: Mendoza, Argentina, 2018; pp. 1-16.

101. Vachon, R.; Hieronymus, C.F. Effect of host-rock rheology on dyke shape, thickness and magma overpressure. Geophys. J. Int. 2017, 208, 1414-1429. [CrossRef]

102. Souche, A.; Galland, O.; Haug, Ø.T.; Dabrowski, M. Impact of host rock heterogeneity on failure around pressurized conduits: Implications for finger-shaped magmatic intrusions. Tectonophysics 2019, 765, 52-63. [CrossRef]

103. Gudmundsson, A.; Loetveit, I.F. Dyke emplacement in a layered and faulted rift zone. J. Volcanol. Geotherm. Res. 2005, 144, 311-327. [CrossRef]

104. Perras, M.A.; Diederichs, M.S. A Review of the Tensile Strength of Rock: Concepts and Testing. Geotech. Geol. Eng. 2014, 32, 525-546. [CrossRef]

105. Petford, N.; Cruden, A.R.; McCaffrey, K.J.W.; Vigneresse, J.L. Granite magma formation, transport and emplacement in the Earth's crust. Nature 2000, 408, 669-673. [CrossRef] [PubMed]

106. Scaillet, B.; Holtz, F.; Pichavant, M. Phase equilibrium constraints on the viscosity of silicic magmas: 1 . Volcanic-plutonic comparison. J. Geophys. Res. Solid Earth 1998, 103, 27257-27266. [CrossRef]

107. Pollard, D.D. Derivation and evaluation of a mechanical model for sheet intrusions. Tectonophysics 1973, 19, 233-269. [CrossRef]

108. Scheibert, J.; Galland, O.; Hafver, A. Inelastic deformation during sill and laccolith emplacement: Insights from an analytic elastoplastic model. J. Geophys. Res. Solid Earth 2017, 122, 923-945. [CrossRef]

109. Rivas-Dorado, S.; Ruiz, J.; Romeo, I. Subsurface Geometry and Emplacement Conditions of a Giant Dike System in Elysium Fossae, Mars. J. Geophys. Res. Planets 2021, 126, e2020JE006512. [CrossRef]

110. Lattard, D.; Engelmann, R.; Kontny, A.; Sauerzapf, U. Curie temperatures of synthetic titanomagnetites in the Fe-Ti-O system: Effects of composition, crystal chemistry, and thermomagnetic methods. J. Geophys. Res. Solid Earth 2006, 111, B12S28. [CrossRef]

111. Petronis, M.S.; O'Driscoll, B.; Lindline, J. Late stage oxide growth associated with hydrothermal alteration of the Western Granite, Isle of Rum, NW Scotland. Geochem. Geophys. Geosyst. 2011, 12, 1-32. [CrossRef]

112. Dunlop, D.J.; Özdemir, Ö. Rock Magnetism. Fundamentals and Frontiers; Cambridge University Press: Cambridge, NY, USA, 1997; Volume 135.

113. Kontny, A.; Grothaus, L. Effects of shock pressure and temperature on titanomagnetite from ICDP cores and target rocks of the El'gygytgyn impact structure, Russia. Stud. Geophys. Geod. 2017, 61, 162-183. [CrossRef]

114. Bilardello, D. Practical Magnetism II: Humps and a Bump, the Maghemite Song The IRM Quarterly. IRM Q. 2020, $30,1-17$.

115. McCabe, C.; Jackson, M.; Ellwood, B.B. Magnetic anisotropy in the Trenton Limestone: Results of a new technique, anisotropy of anhysteretic susceptibility. Geophys. Res. Lett. 1985, 12, 333-336. [CrossRef]

116. Jackson, M. Anisotropy of magnetic remanence: A brief review of mineralogical sources, physical origins, and geological applications, and comparison with susceptibility anisotropy. Pure Appl. Geophys. PAGEOPH 1991, 136, 1-28. [CrossRef]

117. Bilardello, D.; Jackson, M.J. A comparative study of magnetic anisotropy measurement techniques in relation to rock-magnetic properties. Tectonophysics 2014, 629, 39-54. [CrossRef] 
118. Tarling, D.; Hrouda, F. Magnetic Anisotropy of Rocks, 1st ed.; Springer: Amsterdam, The Netherlands, 1993.

119. Bogue, S.W.; Gromme, S.; Hillhouse, J.W. Paleomagnetism, magnetic anisotropy, and mid-Cretaceous paleolatitude of the Duke Island (Alaska) ultramafic complex. Tectonics 1995, 14, 1133-1152. [CrossRef]

120. Stephenson, A.; Sadikun, S.; Potter, D.K. A theoretical and experimental comparison of the anisotropies of magnetic susceptibility and remanence in rocks and minerals. Geophys. J. Int. 1986, 84, 185-200. [CrossRef]

121. Lagroix, F.; Borradaile, G.J. Magnetic fabric interpretation complicated by inclusions in mafic silicates. Tectonophysics 2000, 325, 207-225. [CrossRef]

122. Selkin, P.A.; Gee, J.S.; Meurer, W.P. Magnetic anisotropy as a tracer of crystal accumulation and transport, Middle Banded Series, Stillwater Complex, Montana. Tectonophysics 2014, 629, 123-137. [CrossRef]

123. Renne, P.R.; Scott, G.R.; Glen, J.M.G.; Feinberg, J.M. Oriented inclusions of magnetite in clinopyroxene: Source of stable remanent magnetization in gabbros of the Messum Complex, Namibia. Geochem. Geophys. Geosyst. 2002, 3, 1-11. [CrossRef] 